\title{
Review \\ A Review of Modifications of Quinoline Antimalarials: Mefloquine and (hydroxy)Chloroquine
}

\author{
Dawid J. Kucharski D, Michalina K. Jaszczak and Przemysław J. Boratyński *(D)
}

check for

updates

Citation: Kucharski, D.J.; Jaszczak, M.K.; Boratyński, P.J. A Review of Modifications of Quinoline Antimalarials: Mefloquine and (hydroxy)Chloroquine. Molecules 2022, 27, 1003. https://doi.org/ 10.3390/molecules27031003

Academic Editor:

Philippe M. Loiseau

Received: 11 January 2022

Accepted: 31 January 2022

Published: 2 February 2022

Publisher's Note: MDPI stays neutral with regard to jurisdictional claims in published maps and institutional affiliations.

Copyright: (C) 2022 by the authors. Licensee MDPI, Basel, Switzerland. This article is an open access article distributed under the terms and conditions of the Creative Commons Attribution (CC BY) license (https:// creativecommons.org/licenses/by/ $4.0 /)$.
Department of Organic and Medicinal Chemistry, Wrocław University of Technology, Wyspiańskiego 27, 50-370 Wrocław, Poland; dawid.kucharski@pwr.edu.pl (D.J.K.); 246137@student.pwr.edu.pl (M.K.J.)

* Correspondence: przemyslaw.boratynski@pwr.edu.pl

Abstract: Late-stage modification of drug molecules is a fast method to introduce diversity into the already biologically active scaffold. A notable number of analogs of mefloquine, chloroquine, and hydroxychloroquine have been synthesized, starting from the readily available active pharmaceutical ingredient (API). In the current review, all the modifications sites and reactivity types are summarized and provide insight into the chemistry of these molecules. The approaches include the introduction of simple groups and functionalities. Coupling to other drugs, polymers, or carriers afforded hybrid compounds or conjugates with either easily hydrolyzable or more chemically inert bonds. The utility of some of the compounds was tested in antiprotozoal, antibacterial, and antiproliferative assays, as well as in enantiodifferentiation experiments.

Keywords: mefloquine; chloroquine; hydroxychloroquine; late-stage modification; semisynthesis; derivatization; quinoline

\section{Introduction}

Malaria is an infectious disease, which is responsible for more than 600,000 deaths annually, mainly in tropical areas [1]. It is transmitted by certain Anopheles mosquitos and caused by Plasmodium parasites such as P. knowlesi, P. malariae, P. ovale, P. vivax, and P. falciparum [2]. The last species is the most life-threatening [1,3-5]. People suffering from malaria experience high fever, headaches, nausea, sweat, fatigue, diarrhea, and anemia [1]. The first effective drug against malaria was the Cinchona bark, which contains quinine. While the use of quinine in therapy is rare now, a number of quinoline drugs have been developed to fight malaria (Figure 1). Some of them are very close analogues of quinine, like mefloquine, others fall into 4-aminoquinoline (e.g., chloroquine) and 8-aminoquinoline families (e.g., primaquine). They, in combination with the non-quinoline drug artemisinin, are extensively used. Apart from antiparasitic effects, these medicines exhibit a plethora of biological activities including antibiotic, antitumor, and anti-inflammatory effects [1-4]. The most modern antimalarial medicine, tafenoquine, is an analog of much older primaquine. This exemplifies that the modification of one drug molecule can lead to a new effective analogous drug.

Two general approaches can be adopted. The universal one is to prepare each analog by a de novo synthesis (bottom-up approach). The other is to use an already available natural product or an industrially available active pharmaceutical ingredient (API) and perform further transformations. Such method referred to as semi-synthesis, late-stage modification, or top-down approach, has the advantage of usually being short. Sometimes it is a singlestep process [6,7]. In the case of Cinchona alkaloids, this approach has been used to make analogs that are effective chiral catalysts or show promising antibiotic properties [8-10]. Unlike the natural products [8,9] or the de novo synthesized analogs [11-14], there is no comprehensive review on the late-stage modification of other quinoline drugs. Here we gathered transformations performed on three drugs resembling quinine: mefloquine (MQ), 
chloroquine (CQ), and hydroxychloroquine (HCQ). Whenever the term 'mefloquine' is used, it refers to the erythro enantiomer.<smiles>C=CC1CN2CCC1C2[C@H](O)c1ccnc2ccc(OC)cc12</smiles>

Quinine (natural product)<smiles>O[C@H](c1cc(C(F)(F)F)nc2c(C(F)(F)F)cccc12)[C@@H]1CCCCN1</smiles>
Mefloquine (rac. MQ)

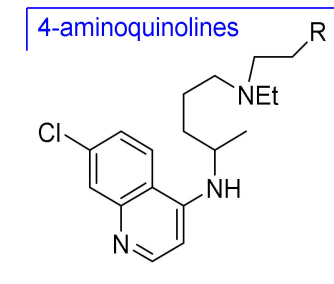

$\mathrm{R}=\mathrm{OH}, \mathrm{Hydroxychloroquine}(\mathrm{HCQ})$

$\mathrm{R}=\mathrm{H}$, Chloroquine $(\mathbf{C Q})$<smiles>CCN(CC)c1cc(Nc2ccnc3cc(Cl)ccc23)ccc1O</smiles>

Amodiaquine

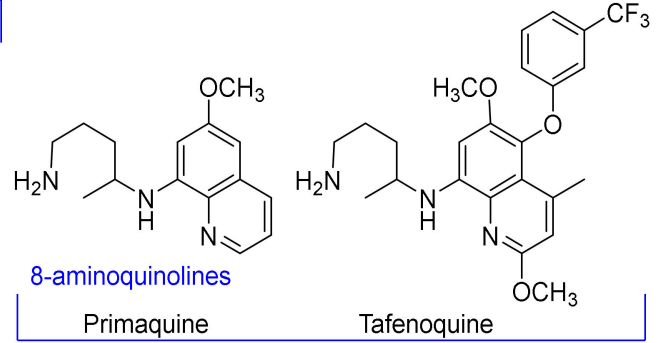

Figure 1. Quinoline antimalarials.

\section{Mefloquine (MQ)}

Mefloquine of erythro configuration was first synthesized in the 1970s (Scheme 1) and soon after sold as a drug (e.g., Lariam; racemic mefloquine hydrochloride). Lutz provided the first record on the synthesis of mefloquine in 1971 [15]. Later works included Wittig rearrangement [16], oxidative decyanation [17], and reactions of sulfoxide with Grignard reagent [18]. Mefloquine can be purchased from specialty chemical suppliers at a price of ca. $20 \mathrm{US} \$ / \mathrm{g}$.
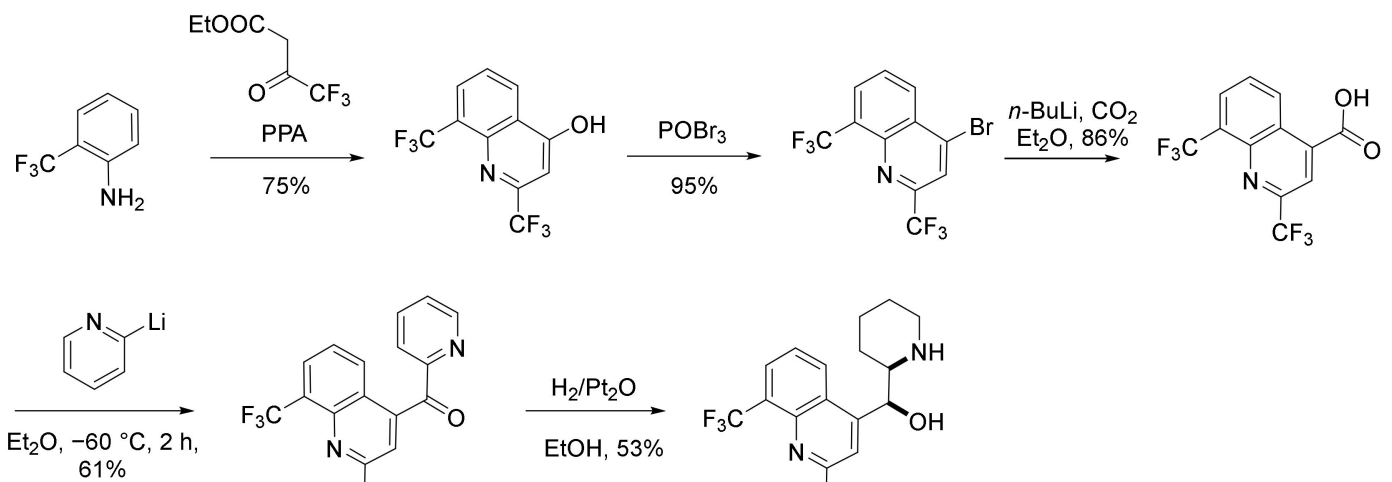<smiles>O=C(c1ccccn1)c1cc(C(F)(F)F)nc2c(C(F)(F)F)cccc12</smiles>

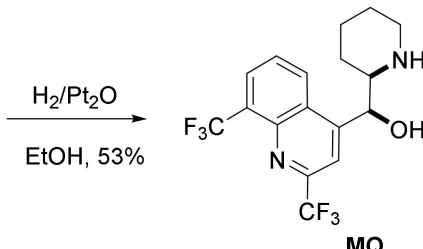

Scheme 1. The first synthesis of mefloquine [15].

In 1974, Carroll and Blackwell presented the separation of erythro-mefloquine enantiomers via 3-bromo-8-camphorsulfonic acid salt [19]. The resolution of the racemic mixture was also conducted with $O, O^{\prime}$-di-p-toluoyl-tartaric acid [20]. The recycling of the material and the use of either enantiomer of the resolving agent provided both enantiomers in a very high yield (86\%) and enantiomeric excess (ee above 99\%) [21].

The first enantioselective synthesis of (-)-erythro-mefloquine via the asymmetric rhodium-catalyzed hydrogenation was reported in 1993 [22,23]. Other enantioselective methods include: asymmetric aldol reaction and the Beckmann rearrangement [24], asymmetric Darzens reaction [25], Pd-catalyzed asymmetric borylative isomerization [26], domino Sonogashira-6r-electrocyclization [27], synthesis from chiral pipecolic acid, enantioselective transfer hydrogenation with ruthenium catalysts [28,29], and the Sharpless asymmetric dihydroxylation [30,31].

Each of the four stereoisomers of mefloquine exhibit slightly different biological properties. For instance, $(-)$-threo and (-)-erythro-mefloquine are up to two times less active against malaria parasites. Moreover, the latter is more toxic than its (+) antipode. It is more likely to cause psychotic behavior, and it remains in the organism for up to 2.5 times longer [26]. Nevertheless, ventures for enantiomerically pure mefloquine have not been commercially successful. 
Mefloquine acts as an antimalarial in the protozoan cytoplasm and targets the Plasmodium falciparum $80 \mathrm{~S}$ ribosome. It was proven that (+)-erythro-mefloquine interacts with residues of PfuL13 such as Leu59 and Glu55 [32]. Mefloquine is slowly metabolized in the liver by cytochrome P450 3A4 (half-life: 3 weeks). The main product of metabolism is carboxymefloquine, which might cause drug interactions [33].<smiles>O=C(O)c1cc(C(F)(F)F)nc2c(C(F)(F)F)cccc12</smiles>

carboxymefloquine

Researchers have strived to enhance the biological activity of mefloquine and circumvent the development of resistance to the drug by modifying mefloquine scaffold, sometimes using late-stage modification rather than synthesizing new analogs de novo. Mefloquine possesses two sites, which have been subject to reactions: position 11 (secondary alcohol), and piperidine nitrogen atom at position 13 (Figure 2). To our knowledge, no reactions at other sites including the quinoline ring have been reported in the literature.<smiles>CCCCC[C@@H](N)[C@H](O)c1cc(C(F)(F)F)nc2c(C(F)(F)F)cccc12</smiles>

site of frequent modifications

site of rare modifications

(+)-Mefloquine (MQ)

Figure 2. Structure, modification sites, and traditional atom numbering of mefloquine.

\subsection{Position 13}

\subsubsection{Amides}

Mefloquine acetamide MQ-1 was produced by either one-step mono-acetylation by acetic anhydride in isopropanol at room temperature or via selective hydrolysis of diacetyl derivative MQ-2 with $\mathrm{LiOH}$ in methanol $[19,21]$.<smiles>CC(C)(F)c1cc([C@H](O)[C@H]2CCCCN2)c2cccc(C(F)(F)F)c2n1</smiles><smiles>[R]C(=O)OCCO</smiles><smiles>CC(=O)O[C@H](c1cc(C(F)(F)F)nc2c(C(F)(F)F)cccc12)C1CCCCN1C(C)=O</smiles>

MQ-2

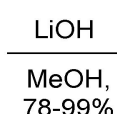
$78-99 \%$ (2 steps)<smiles>CC(=O)N1CCCC[C@H]1[C@H](O)c1cc(C(F)(F)F)nc2c(C(F)(F)F)cccc12</smiles>

MQ-1

$$
\mathrm{Ac}_{2} \mathrm{O}, \mathrm{K}_{2} \mathrm{CO}_{3}
$$

IPA, rt

The amide of succinic acid MQ-5 was obtained effectively using a three-step approach. To assure selectivity, the authors chose trimethylsilyl (TMS) ether protection for the 11hydroxy group. The acylation with methyl succinyl chloride in the presence of pyridine gave the corresponding amide MQ-4 an excellent yield. Finally, removal of the protecting group was done with fluoride (TBAF) [34]. 
<smiles>OC(c1cc(C(F)(F)F)nc2c(C(F)(F)F)cccc12)C1CCCCN1</smiles>

MQ
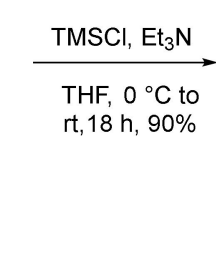<smiles>COC(c1cc(C(F)(F)F)nc2c(C(F)(F)F)cccc12)C1CCCCN1</smiles>

MQ-3<smiles>COC(=O)CCC(=O)Cl</smiles>
$0^{\circ} \mathrm{C}$ to rt, $18 \mathrm{~h}, 81 \%$<smiles>[R]C(c1cc(C(F)(F)F)nc2c(C(F)(F)F)cccc12)C1CCCCN1C(=O)CCC(=O)OC</smiles>

$n-\mathrm{Bu}_{4} \mathrm{NF} \cdot 3 \mathrm{H}_{2} \mathrm{O}$

$$
\mathrm{R}=\text { OTMS MQ-4 }
$$

$\mathrm{R}=\mathrm{OH}$

MQ-5

(+)-erythro-Mefloquine was acylated with Mosher's acid using $\alpha$-methoxy- $\alpha$-(trifluoro methyl)phenylacetyl chloride (MTPA-Cl) in the presence of $N, N$-diisopropylethylamine (DIPEA). Reactions with both enantiomers of MTPA-Cl were performed, but only (R)-MTPA-Cl reacted quantitatively. The absolute configuration of (+)-erythro-mefloquine hydrochloride was determined as $(11 S, 12 R)$ by single-crystal $X$-ray. The synthesis starting from the racemic erythro-mefloquine yielded two amide diastereoisomers for each enantiomer of MTPA-Cl. The products presented differences in $R_{\mathrm{f}}$ values and were successfully separated [35].

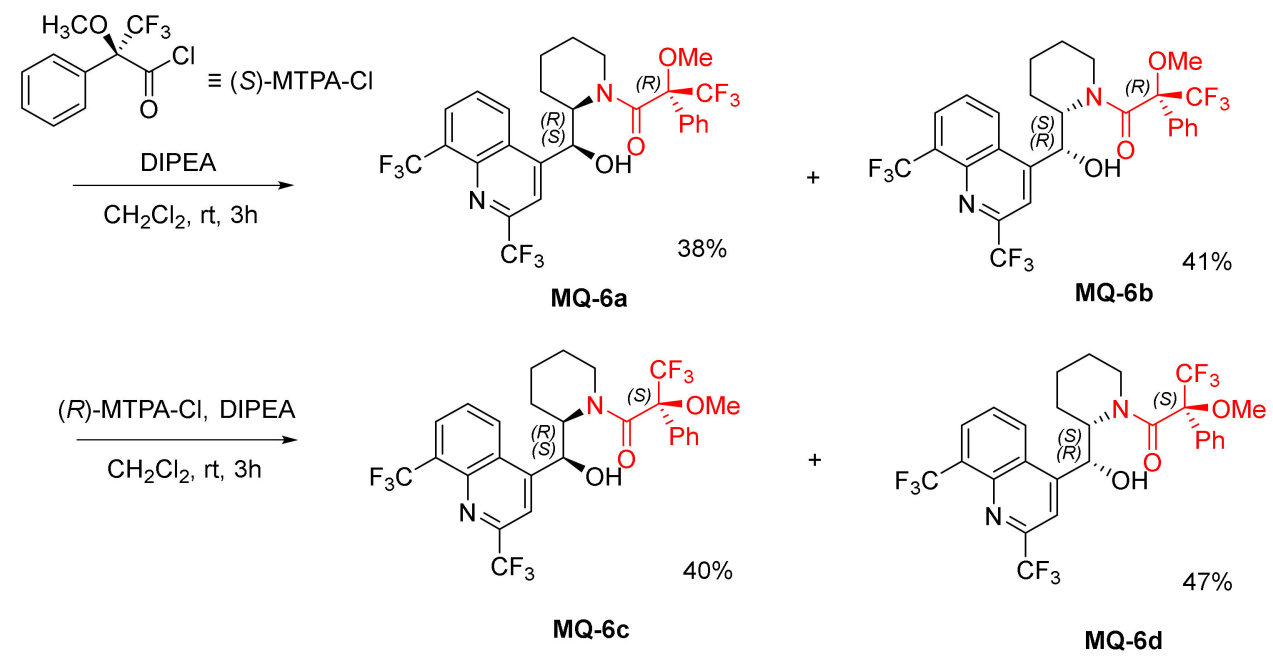

Both (+)-erythro and (-)-threo-mefloquine were treated with $(S)-(+)$-mandelic acid $t$-butyldimethylsilyl ether activated by uranium salt (1-[bis(dimethylamino)methylene]$1 H$-1,2,3-triazolo [4,5- $b$ ]pyridinium hexafluorophosphate $N$-oxide, HATU) in the presence of DIPEA. The X-ray structures of the products MQ-7 and MQ-9 were used to prove the absolute stereochemistry of $(+)-(11 S, 12 R)$-erythro-mefloquine and (-)-(11R,12R)-threomefloquine [29,30].<smiles>OC(c1cc(C(F)(F)F)nc2c(C(F)(F)F)cccc12)C1CCCCN1</smiles>

(+)-MQ<smiles>O[C@H](c1cc(C(F)(F)F)nc2c(C(F)(F)F)cccc12)[C@@H]1CCCCN1</smiles>

(-)-threo-mefloquine (MQ-8)
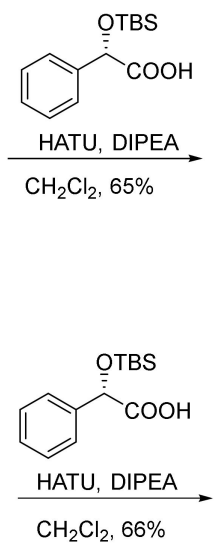

$\mathrm{CH}_{2} \mathrm{Cl}_{2}, 66 \%$

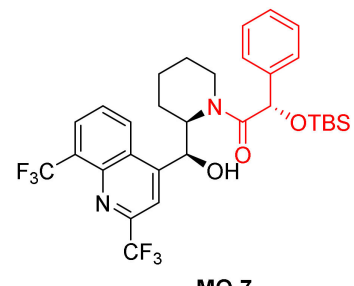<smiles>O=C([C@H](O[C@H](O)c1ccccc1)c1ccccc1)N1CCCC[C@H]1[C@H](O)c1cc(C(F)(F)F)nc2c(C(F)(F)F)cccc12</smiles> 
Racemic mefloquine was subjected to the kinetic resolution using polymer reagent for amine resolution ( $\alpha$-PEARL). The use of the chiral active ester of phenylpropionic acid gave corresponding enantioenriched amide MQ-10, while the unreacted MQ was enantiomerically pure [36].

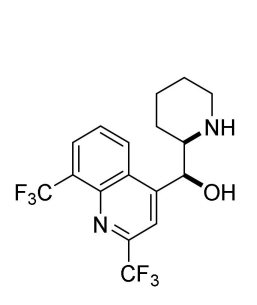

rac. MQ

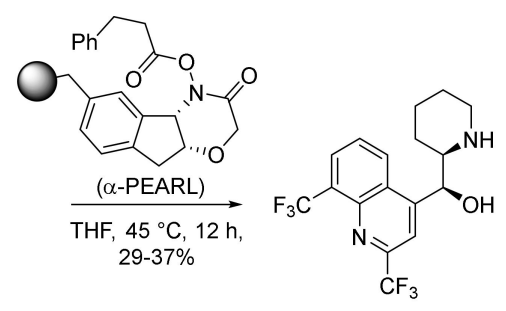

$(+)-\mathbf{M Q}$ e.r. $>99: 1$

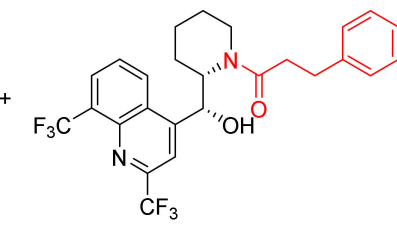

enantiomerically enriched MQ-10

In a parallel kinetic application, two different polymer-supported acylating reagents (pent-4-enoate and $o$-nitrophenylpropionate) with different configurations were applied at once in the reaction with racemic mefloquine. This time a mixture of enantiomerically pure amides MQ-11 and MQ-12 was obtained. Both products underwent selective deacylation: pent-4-enamide MQ-11 with iodine, while $o$-nitrophenylpropionamide MQ-12 with reduction of the nitro group, followed by mild acidic treatment resulting in intramolecular lactonization. The sequential process allowed for the separation of mefloquine enantiomers without the loss of enantiomeric purity [37].
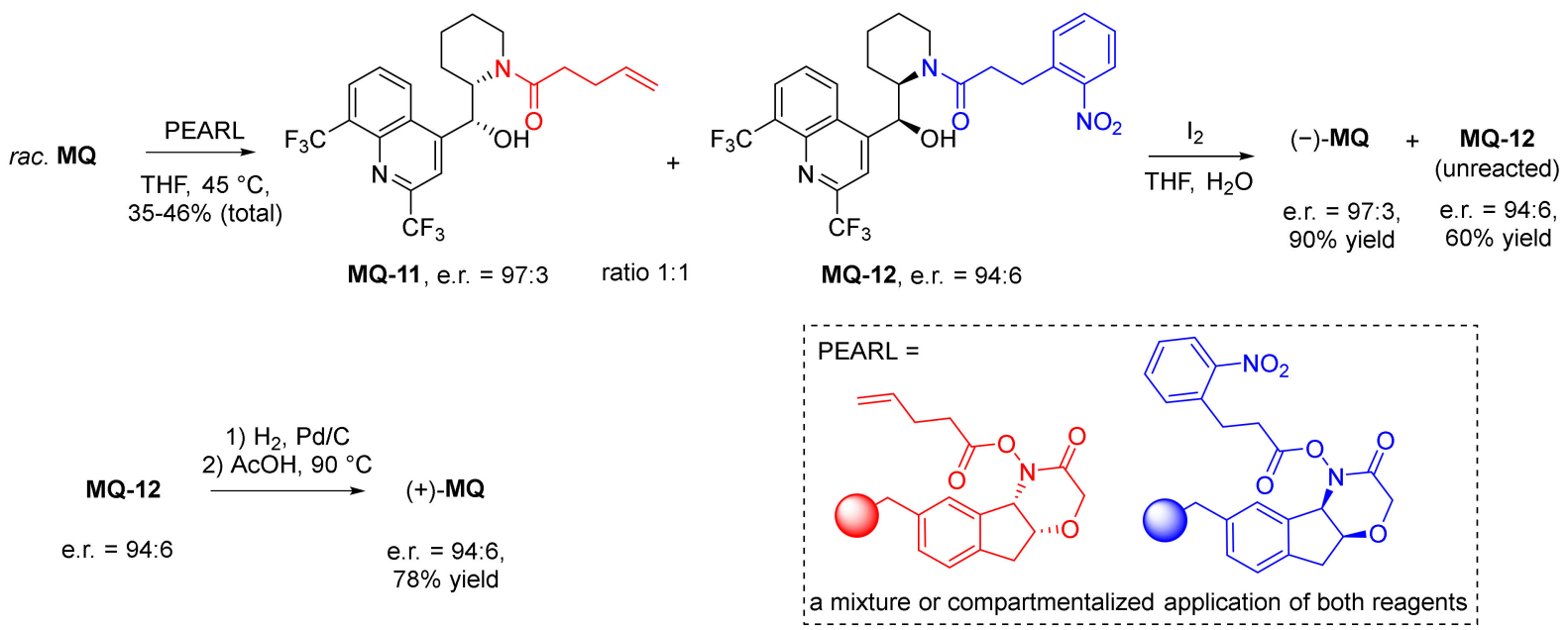

\subsubsection{Urethane}

Since mefloquine possesses two reactive sites, the use of protective groups was planned to ensure chemoselectivity. For example, the tert-butyloxycarbonyl (Boc) protecting group was introduced at the nitrogen 13 atom in mefloquine. The deprotection can be conducted using TFA in $\mathrm{CH}_{2} \mathrm{Cl}_{2}$ [34].<smiles>CC(C)(F)c1cc(C(O)C2CCCCN2)c2cccc(C(F)(F)F)c2n1</smiles>

MQ<smiles>CC(=O)OC(O)C1CCCCN1C(=O)OCc1cc(C(F)(F)F)nc2c(C(F)(F)F)cccc12</smiles>

MQ-13

Polycyclic peroxide carbamate MQ-14a was formed from mefloquine hydrochloride and functionalized nitrophenyl carbonate (racemate, prepared from 3-hydroxycyclohexanone in a four-step sequence) in the presence of $4-(N, N$-dimethylamino)pyridine (DMAP) and DIPEA. The product MQ-14a was obtained as an inseparable mixture of four diastereoisomers in a fair 
yield. Trioxolane-mediated drug delivery was devised to alleviate the toxicity of mefloquine. It was proven that due to the low brain penetration of the 3 "-trioxolane conjugate, decreased brain concentrations of mefloquine were found in mice treated with MQ-14a than in the animals on the unmodified drug. It was assumed that when Plasmodium digested hemoglobin and heme was produced, iron(II) induced the cleavage of the endoperoxide bond in the conjugate by means of a Fenton-like reaction. This affords a ketone, which releases mefloquine after decarboxylation. The antimalarial activity of the conjugate MQ-14a against P. falciparum W2 strain was similar to the parent compound and arterolane $\left(\mathrm{EC}_{50} 2.5-3.0 \mathrm{nM}\right)$ [38].<smiles>OC(c1cc(C(F)(F)F)nc2c(C(F)(F)F)cccc12)C1CCCCN1</smiles>

$M Q \cdot H C l$

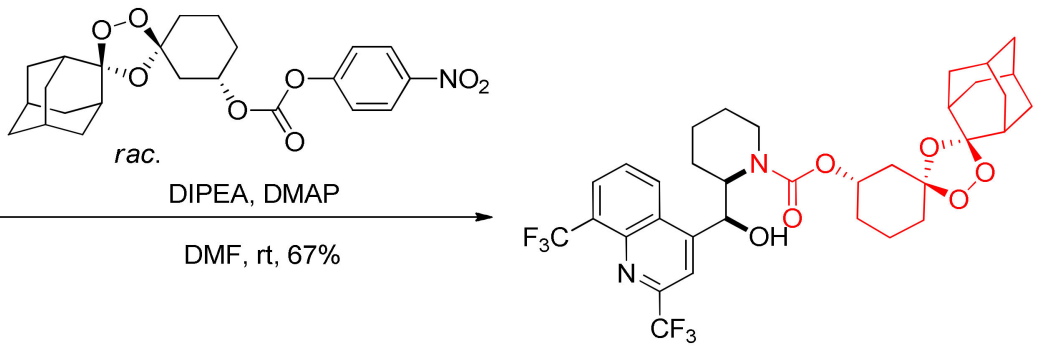

MQ-14a (isomer mixture)

More carbamates (MQ-14b-d) were prepared from sterically shielded trioxolanes. Their activity $\left(\mathrm{IC}_{50}: 24-74 \mathrm{nM}\right)$ against $P$. falciparum $\mathrm{W} 2$ was higher than for chloroquine, yet lower than for artefenomel ( $\mathrm{IC}_{50}$ : 285 and $9.0 \mathrm{nM}$, correspondingly) [39].

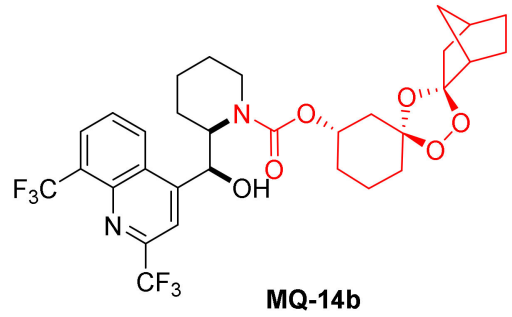

MQ-14b

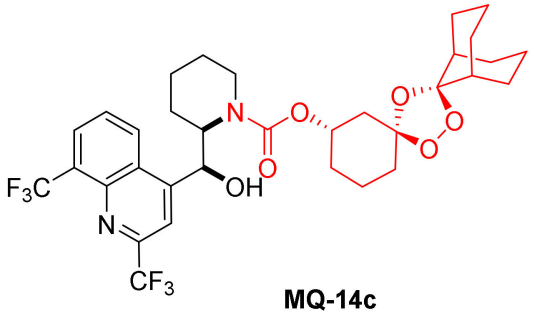

MQ-14c<smiles>COC(=O)N1CCCCC1C(O)c1cc(C(F)(F)F)nc2c(C(F)(F)F)cccc12</smiles>

\subsection{3. (thio)Urea}

4-Chlorophenyl isocyanate reacted with mefloquine in the presence of a base $\left(\mathrm{Et}_{3} \mathrm{~N}\right)$ to form the corresponding urea MQ-15 in a fair yield. The product displayed moderate antituberculotic activity [40].<smiles>OC(c1cc(C(F)(F)F)nc2c(C(F)(F)F)cccc12)C1CCCCN1</smiles>

MQ<smiles>O=[N+]([O-])c1ccc(Cl)cc1</smiles>

THF, $0^{\circ} \mathrm{C}$ to $\mathrm{rt}, 4 \mathrm{~h}, 52 \%$<smiles>CCCCC(F)(C(F)(F)F)C(F)(F)F</smiles>

MQ-15

erythro-Mefloquine reacted with allyl isothiocyanate to form $13-N$-allylthiourea derivative MQ-16 in a very good yield. The X-ray crystal structure of this mefloquine derivative provided proof for the absolute stereochemistry directly based on anomalous scattering [41].<smiles>OC(c1cc(C(F)(F)F)nc2c(C(F)(F)F)cccc12)C1CCCCN1</smiles>

MQ

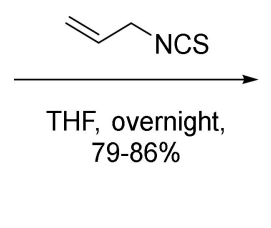<smiles>C=CCNC(=S)N1CCCCC1C(O)c1cc(C(F)(F)F)nc2c(C(F)(F)F)cccc12</smiles>

MQ-16 


\subsubsection{Alkyl Derivatives}

A series of $N$-substituted mefloquine derivatives was prepared using alkyl bromides, in the presence of a base $\left(\mathrm{K}_{2} \mathrm{CO}_{3}\right.$ or $\left.\mathrm{Et}_{3} \mathrm{~N}\right)$ in poor to moderate yields. The mefloquinederived tertiary amines MQ-17-23 were investigated as potential anti-tuberculotic (antiTB) agents. It transpired that the presence of the benzyl group at the N-13 atom in mefloquine increased the activity of MQ-20 against Mycobacterium tuberculosis $\mathrm{H}_{37} \mathrm{Rv}$ in respect to (+)-erythro-mefloquine hydrochloride with MIC: $6.7 \mu \mathrm{M}$ in MABA (microplate alamarBlue assay) and 7.3 $\mu \mathrm{M}$ in LORA (low oxygen recovery assay). Additionally, the benzyl derivative MQ-20 exhibited low cytotoxicity. However, the 4-pyridylmethyl compound MQ-22 was approximately 70\% less active than erythro- $N$-benzylmefloquine MQ-20. Polar electron-withdrawing substituents in the para position of the benzyl group (sulfonamido or carboxyl groups) also decreased the anti-TB activity. No activity was observed for compounds with acetic acid MQ-17 and acetamide residues MQ-18 as substituents. In the same assay, the urea MQ-15 and 13-Boc-mefloquine MQ-13 showed moderate activity [40].

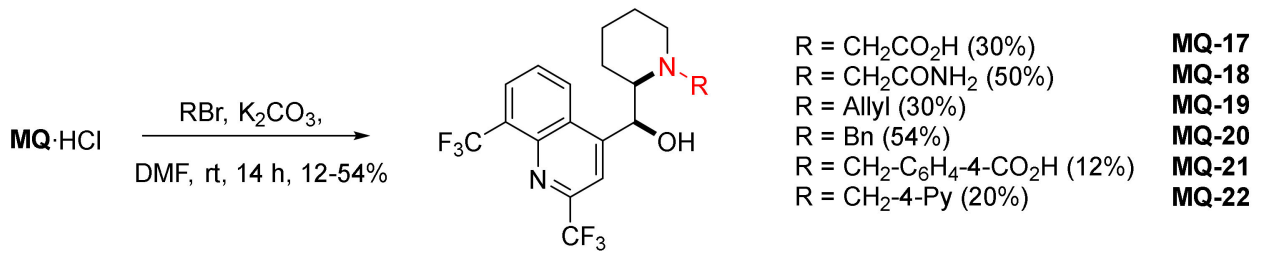

MQ-17-22

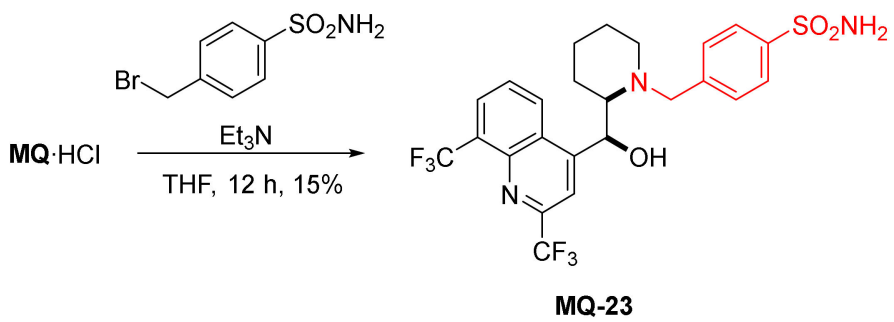

A conjugate of artemisinin, an established antimalarial drug, and mefloquine was prepared. The piperidinyl amino group (N-13) of mefloquine was alkylated using allyl bromide derived from $10-\mathrm{CF}_{3}$-artemisinin in the presence of triethylamine resulting in the formation of the tertiary amine MQ-24 in a moderate yield. Under these conditions, the hydroxy group is unaffected. The link between both drugs in MQ-24 is not hydrolyzable [34].<smiles>OC(c1cc(C(F)(F)F)nc2c(C(F)(F)F)cccc12)C1CCCCN1</smiles>

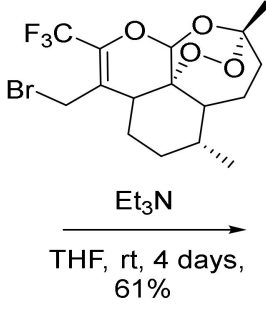

MQ<smiles>CC1=C(CN2CCCCC2C(O)c2cc(C(F)(F)F)nc3c(C(F)(F)F)cccc23)C2CC[C@@H](C)C3CCC(C)OC23OC1</smiles>

MQ-24

erythro-13-Methylmefloquine was prepared in the Eschweiler-Clarke reaction using formic acid and formaldehyde. The tertiary amine MQ-25 was further converted to the $N$-oxide MQ-26 by the oxidation with $m$-chloroperoxybenzoic acid. Both products were obtained in a fair yield. Unlike erythro-mefloquine, compounds MQ-25 and MQ-26 exhibited no contractual effect on the isolated mouse diaphragm and no inhibition of directly simulated twitch response [42]. 
<smiles>OC(c1cc(C(F)(F)F)nc2c(C(F)(F)F)cccc12)C1CCCCN1</smiles>

$M Q \cdot H C l$

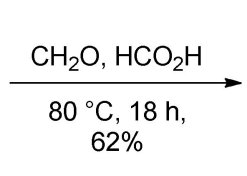

MQ-25·HC<smiles>C[N+]1(O)CCCCC1C(O)c1cc(C(F)(F)F)nc2c(C(F)(F)F)cccc12</smiles>

$M Q-26 \cdot H C l$

In a similar approach, the cyanoethyl alkylated product MQ-27 was obtained in the Michael addition. The corresponding reaction of mefloquine and acrylonitrile gave a very good yield. Next, oxidation with $m$-chloroperoxybenzoic acid afforded hydroxylamine MQ-28. Hypervalent iodine(III) reagents are capable of trifluoromethylating $N, N$-dialkylhydroxylamines. Here, the reaction of MQ-28 with Togni reagent accomplished trifluoromethylation at the $N$-hydroxy group affording the ether MQ-29. In order to improve chemoselectivity, the authors decided to both activate the hypervalent iodine reagent with a Lewis acid and deprotonate MQ-28 with an adequate base, therefore trimethylsilyl triflate (TMSOTf) and tetramethylguanidine (TMG) were used. The mechanism involved nitroxyl and $\mathrm{CF}_{3}$ radicals. The native 11-hydroxy group in mefloquine did not react under these conditions [43].
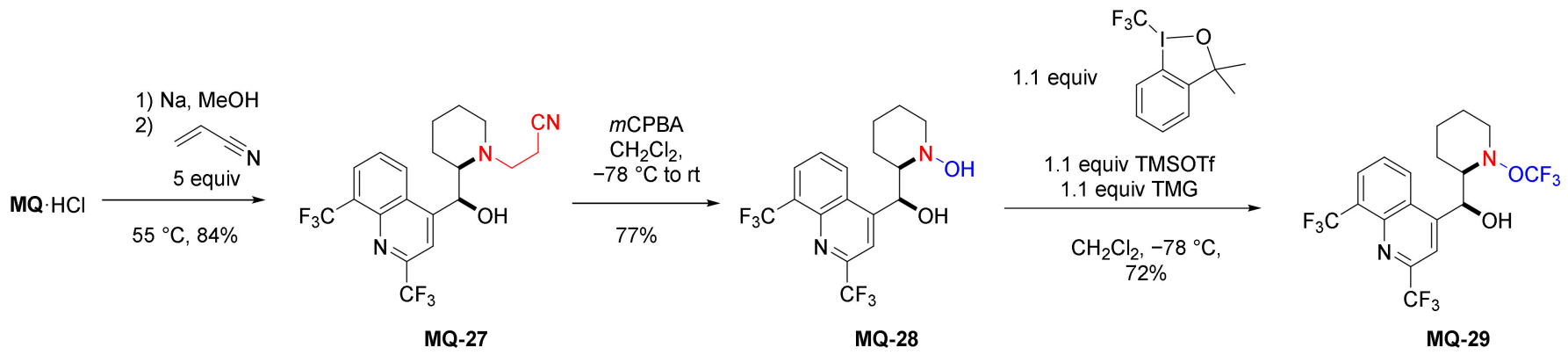

Mefloquine underwent stereospecific strain-release cyclopentylation with chiral 1sulfonyl-bicyclo [2.1.0]pentane (housane) acting as a covalent reactive group. The reaction yielded a disubstituted cyclopentane derivative MQ-30 and a complete stereotransfer was observed. The difference in reactivity of racemic and enantiopure sulfone reagent was negligible (35 and 32\% yield, respectively). The secondary amino group reacted chemoselectively and the hydroxy group remained unaffected [44].<smiles>OC(c1cc(C(F)(F)F)nc2c(C(F)(F)F)cccc12)C1CCCCN1</smiles>

$M Q \cdot H C l$

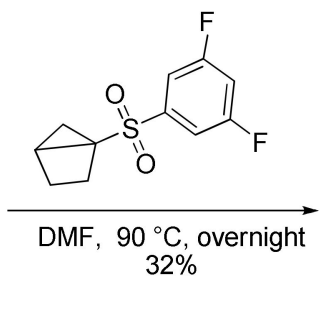

(1)<smiles>O=S(=O)(c1cc(F)cc(F)c1)C1CCC(N2CCCCC2C(O)c2cc(C(F)(F)F)nc3c(C(F)(F)F)cccc23)C1</smiles>

MQ-30

$99 \%$ ee

\subsection{Position C-11}

\subsubsection{1-Inversion}

erythro-Mefloquine can be converted to the threo isomer MQ-8 in a three to fourstep process. (+)-(11R,12S)-N-acetyl mefloquine (MQ-1) under treatment with thionyl chloride undergoes rearrangement via a probable oxazolinium species to the $O$-acetyl derivative MQ-31 with inversion of configuration at position 11 . Acid hydrolysis affords $(+)-(11 S, 12 S)$-threomefloquine hydrochloride $\mathbf{M Q - 8} \cdot \mathrm{HCl}$ in an excellent overall yield. Tests on mice showed that neither isomer exhibited substantial differences in activity against $P$. berghei [19]. 
<smiles>CC(C)(C)OC(=O)N1CCCCC1C(O)c1cc(C(F)(F)F)nc2c(C(F)(F)F)cccc12</smiles>

MQ-13

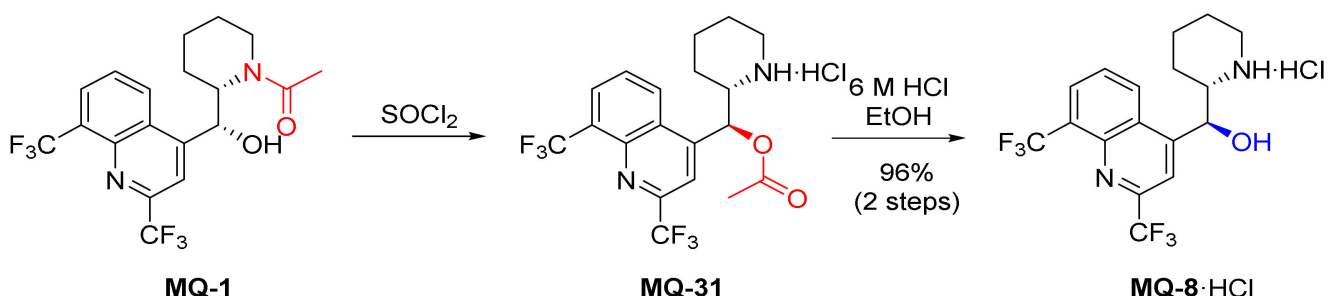

\subsubsection{1-Ketone}

Rutjes and Vlieg presented a method for the deracemization of erythro-mefloquine. First, the Boc-protecting group at the $\mathrm{N}-13$ atom was introduced. Then, the secondary alcohol was converted to the corresponding ketone MQ-32 in the Dess-Martin oxidation. In the process, one stereogenic center at position 11 was completely lost, while the remaining stereogenic center was labile due to tautomerization. Strong acids such as $\mathrm{HCl}$ and a vast number of sulfonic acids were screened for the removal of Boc and crystallization of salts in the form of a racemic conglomerate. Out of more than 30 crystal structures, only MQ-33.di(biphenylsulfonate) dihydrate formed the racemic conglomerate and allowed for the resolution of enantiomers using Viedma ripening. Eventually, the resolved ketone MQ-33 was reduced with $\mathrm{NaBH}_{4}$ to the (+)-(11S,12R)-erythro-mefloquine. The overall yield was $83 \%$ [45].

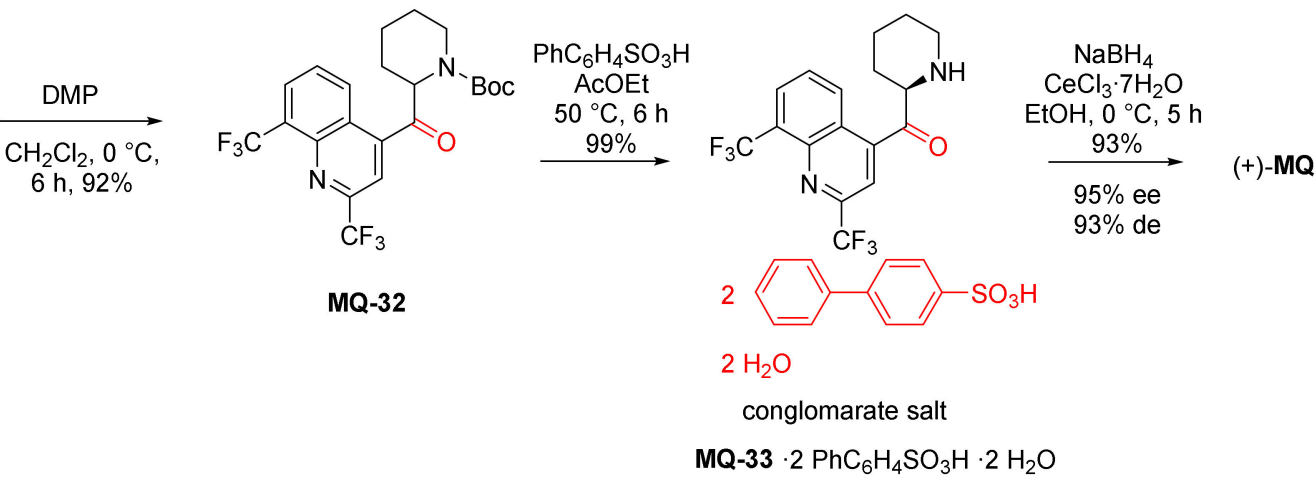

\subsubsection{Photochemical Degradation}

Generally, mefloquine exhibits low phototoxicity. Photodegradation occurs more effectively at higher $\mathrm{pH}$. Carbon 11-centered benzyl type radical was postulated as a precursor for all the observed degradation products. Subsequent reactions lead to the cleavage of adjacent bonds. A number of products have been identified after irradiation in water [46,47]. In methanol, photodegradation essentially leads to two defined products arising from the cleavage of the C-11-C-12 bond, mostly carboxymefloquine methyl ester (MQ-34a, 55\% yield) and a small quantity of corresponding benzyl alcohol MQ-34b [48]. 
<smiles>[R]C=CC(=O)OCC(=O)OO</smiles>

MQ
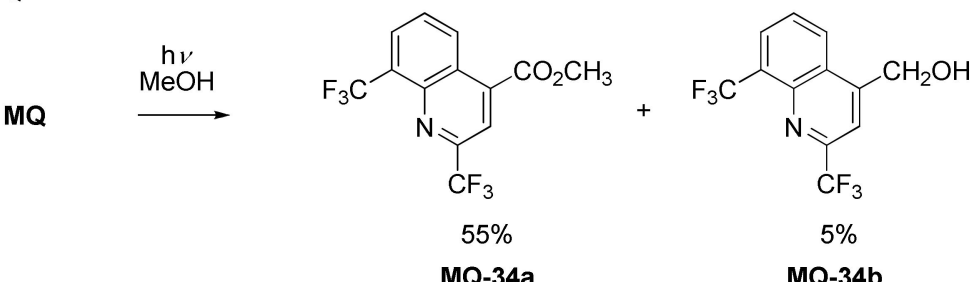

$5 \%$

MQ-34b

\subsection{Position $0-11$}

Despite the wide reactivity of Cinchona alkaloids at their central hydroxy group, much less chemistry has been performed solely with the hydroxy group of mefloquine. Only the TMS group has been introduced selectively (vide supra) [34]. All the remaining cases resort to the use of a protecting group at the nitrogen 13 atom to achieve selective reactivity of the hydroxy group.

\subsubsection{Esters}

Boc-protected mefloquine (MQ-13) reacted with succinic and glutaric anhydrides to obtain ester acids homologs MQ-35 and MQ-36. Then, carboxylic acid groups were transiently converted to acyl chlorides with thionyl chloride and used to acylate hydroxy group of atovaquone (ATQ), another antimalarial drug. The overall yields were rather poor. During the process, the Boc group was partially removed from the succinic derivative, giving a mixture of the protected (MQ-37, 21\% yield) and the deprotected product (MQ-38, $11 \%$ yield). Treatment of MQ-37 with methanolic $\mathrm{HCl}$ removes Boc in an excellent yield. The esterification process of homologous MQ-36 resulted only in the deprotected product MQ-39. Both the derivatives MQ-38 and MQ-39 turned out to be more active ( $\mathrm{IC}_{50}$ : 0.6-1.1 nM) against $P$. falciparum F32-TEM than the unmodified drugs $\mathbf{M Q}$ and atovaquone $\left(\mathrm{IC}_{50}: 87\right.$ and $\left.2 \mathrm{nM}\right)[49]$.<smiles>CC(C)(C)c1cc(C(O)C2CCCCN2C(=O)c2ccccc2)c2cccc(C(F)(F)F)c2n1</smiles>

MQ-13
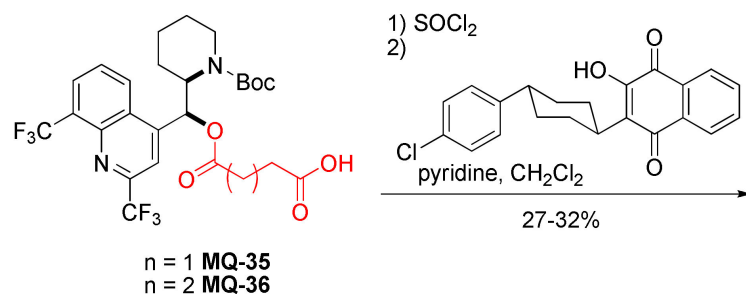

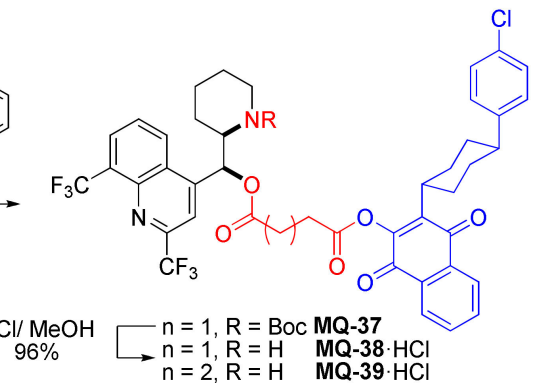

In a preceding approach, mefloquine was linked to artemisinin using an ester linker. The reaction of ester carboxylic acid MQ-35 with hydroxyether artemisinin derivative was performed under carbodiimide activation in the presence of DMAP. The corresponding product MQ-40 was isolated in a good yield. Finally, removal of the Boc-protecting group with TFA afforded the drug conjugate MQ-41 in only a fair yield. Under these conditions, some transfer of acyl group from oxygen 11 to nitrogen 13 atom occurred, resulting in amidoester by-product MQ-42 [34]. This reaction did not occur in the synthesis of MQ-38 and MQ-39 [49]. 
<smiles>CC(C)(C)OC(=O)N1CCCCC1C(OC(=O)CCC(=O)O)c1cc(C(F)(F)F)nc2c(C(F)(F)F)cccc12</smiles>

MQ-35

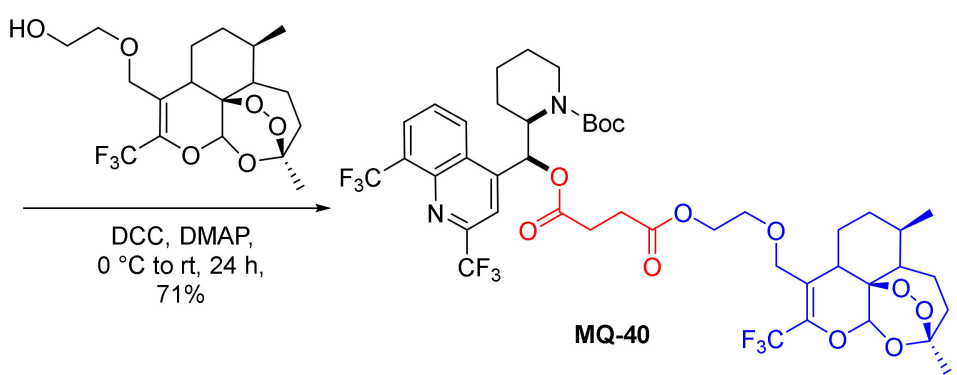<smiles>CC1CCC2C(COCCOC(=O)CCC(=O)OC(c3cc(C(F)(F)F)nc4c(C(F)(F)F)cccc34)C3CCCCN3)=C(C(F)(F)F)OC3OC4(C)CCC1C32OO4</smiles>

57\%, MQ-41<smiles>CC1CCC2C(C)CCC3C(COCCOC(=O)CCC(=O)N4CCCCC4C(O)c4cc(C(F)(F)F)nc5c(C(F)(F)F)cccc45)=C(C(F)(F)F)OC(O1)C32O</smiles>

The ester linkage was devised to bond together $\mathrm{CF}_{3}$-artemisinin and mefloquine into a hybrid molecule, in which in vivo hydrolysis could release both drugs. Compounds MQ-41 and MQ-24 (vide supra) were highly effective against P. falciparum (strains: F32, Thai, FcB1, and K1). It is noteworthy that the ester MQ-41 performed better than the permanently linked tertiary amine MQ-24 ( $\mathrm{IC}_{50}$ : 2.4-6 vs. 10-17 nM, respectively) as well as unmodified mefloquine and chloroquine ( $\mathrm{IC}_{50}: 2.8-23$ and $14-183 \mathrm{nM}$, correspondingly). No cross-resistance with $C Q$ or MQ was observed for MQ-24. The authors recognized their products as a part of covalent bi-therapy, which aims to increase the therapeutic effect of a drug and decrease the possibility of drug resistance. The synthesized compounds consist of two biologically active modules. Such an approach has been reported to be effective in the case of synthetic endoperoxide-chloroquine and statine-primaquine derivatives. The mefloquine and 10-trifluoromethyl artemisinin combination improved metabolic stability and increased activity when compared to other artemisinin-based compounds [34].

\subsubsection{Carbamates}

The use of Cinchona alkaloid carbamates in enantioselective separations by Lindner and coworkers resulted in the development of commercial products [50]. In 2001, the same group reported racemic mefloquine-O-tert-butylcarbamate MQ-44 obtained in a three-step sequence. The product MQ-44 along with a few different chiral compounds was tested as a basic selectand for the performance test of (S)-3,5-dinitrobenzoyl-leucine chiral selector in nonaqueous capillary electrochromatography (CEC). The experiment proved that the separations relying on stereoselective ion-pair formation between the selector and the selectands proceeded in excellent stereoselectivity [51]. In subsequent works, MQ-44 was used in performance tests of multiple chiral stationary phases (CSP) in CEC [52-57], HPLC [58-61], and supercritical fluid chromatographic (SFC) separations [62,63]. In all cases, strong ion exchangers were needed to achieve good separations.<smiles>O=C(OC(=O)C(F)(F)F)N1CCCCC1C(O)c1cc(C(F)(F)F)nc2c(C(F)(F)F)cccc12</smiles>

MQ-13<smiles>CC(C)(C)[N+](=O)[O-]</smiles><smiles>CC(C)(C)NC(=O)OC(c1cc(C(F)(F)F)nc2c(C(F)(F)F)cccc12)C1CCCCN1C(=O)OC(C)(C)C</smiles>

MQ-43<smiles>CC(C)(C)NC(=O)OC(c1cc(C(F)(F)F)nc2c(C(F)(F)F)cccc12)C1CCCCN1</smiles>

MQ-44 
The works by Lindner also mention enantioseparations of some 13-alkyl mefloquine derivatives (N-allyl MQ-19, N-methyl MQ-25, $N$-undecen-1-yl-mefloquine) and N-allyl-Otert-butylcarbamoylmefloquine MQ-46 [62,64]. The enantiomerically pure allyl derivative MQ-19 was obtained by resolution of diastereomeric $\mathrm{O}, \mathrm{O}$-diacetyl-L-tartaric acid esters MQ-45. The reaction of MQ-19 with tert-butyl isocyanate catalyzed by dibutyltin laurate gave the corresponding carbamate MQ-46 in a very good yield [64].<smiles>C=CCN1CCCCC1C(O)c1cc(C(F)(F)F)nc2c(C(F)(F)F)cccc12</smiles>

MQ-19<smiles>CCO[C@H]1C(=O)OC(=O)[C@@H]1OC(C)C</smiles><smiles>[R]C(c1cc(C(F)(F)F)nc2c(C(F)(F)F)cccc12)C1CCCCN1CC=C</smiles>

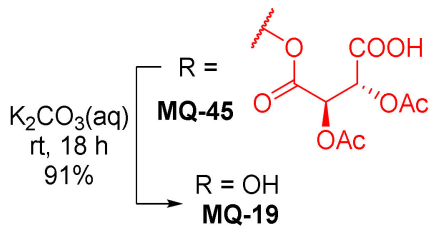<smiles>C=CCN1CCCCC1C(OC(=O)NC(C)(C)C)c1cc(C(F)(F)F)nc2c(C(F)(F)F)cccc12</smiles>

MQ-46

\subsection{Modifications Involving Both Positions 11 and 13}

erythro-Mefloquine was methylated at two positions at once when deprotonated with sodium hydride and reacted with iodomethane. The transformation resulted in the tertiary amine ether MQ-47 in a moderate yield [65].<smiles>O[C@H](c1cc(C(F)(F)F)nc2c(C(F)(F)F)cccc12)C1CCCCN1</smiles>

MQ

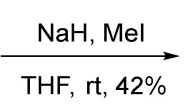<smiles>CO[C@H](c1cc(C(F)(F)F)nc2c(C(F)(F)F)cccc12)C1CCCCN1C</smiles>

MQ-47

Acetylation under forceful conditions with acetyl anhydride at above $90{ }^{\circ} \mathrm{C}$ resulted in the diacetyl product MQ-2 (vide supra) [66]. Similarly, fatty acid chlorides were used to $\mathrm{N}, \mathrm{O}$-diacylate mefloquine. Reactions with palmitoyl and oleoyl chlorides in the presence of catalytic DMAP resulted in very good yields of products MQ-48 and MQ-49. These products were characterized by increased lipophilicity, three-times better solubility in oil, and were, therefore, suitable for use in lipid emulsions. Subsequently, the products were contained in $20 \%$ sesame oil-in-water submicron emulsions, which were physically stable. However, their antimalarial activity was completely lost [67].<smiles>OC(c1cc(C(F)(F)F)nc2c(C(F)(F)F)cccc12)C1CCCCN1</smiles>

$M Q \cdot H C l$

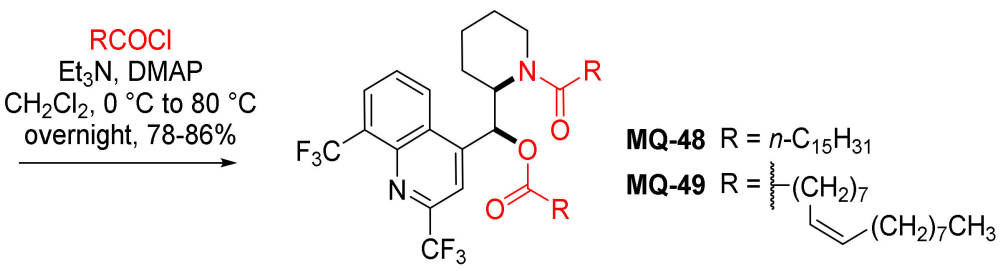

\subsubsection{Heterocyclic Derivatives: Aziridine Ring and Ring-Opening Reactions}

erythro-Mefloquine, under the Appel reaction conditions, undergoes dehydration to form aziridine MQ-50 with inversion of configuration (threo) as shown by Rösner and Brossi. The reaction was carried out with mefloquine free base, triphenylphosphine, triethylamine, and carbon tetrachloride in acetonitrile. The product MQ-50 was obtained in a fair yield and its structure was confirmed with X-ray. In the solid phase, the aziridine MQ-50 
displays photochromic properties: Upon irradiation of the colorless product with UV light $(366 \mathrm{~nm})$, it changes color to purple, which disappears more slowly when kept in the dark. Nonetheless, the process does not induce decomposition of the compound. The aziridine MQ-50 reacts with acetic anhydride at room temperature to form the erythro- $N, O$-diacetyl derivative MQ-2, identical to that obtained by reacting erythro-mefloquine with acetic anhydride at $90^{\circ} \mathrm{C}$. In this sequence of reactions, configuration of the initial mefloquine is retained [66]. Attempts to obtain the erythro-diastereoisomer of aziridine were unsuccessful.

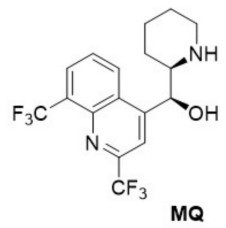

$M Q$

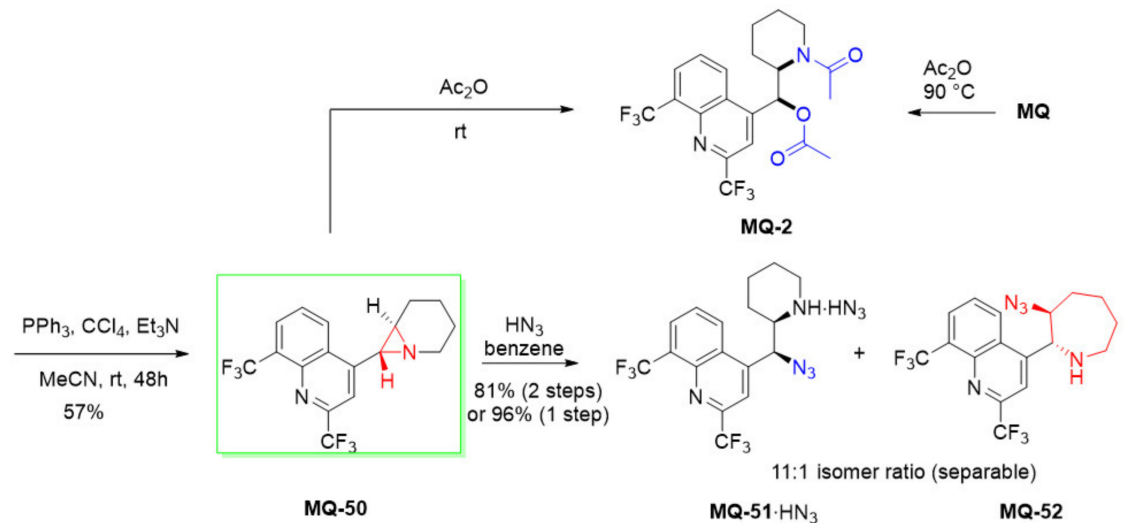

Ring-opening of the aziridine MQ-50 with hydrazoic acid produced the corresponding azide MQ-51 very efficiently. In addition, a small contribution of ring-opening at the alternative site resulted in the isolation of azide with azepane ring MQ-52. The yield of azides from the pure aziridine was nearly quantitative, while a two-step process without proper purification of the aziridine MQ-50 resulted in $81 \%$ yield. This suggests that the aziridine is formed more efficiently than it is isolated. The aminoazide MQ-51 was quantitatively hydrogenated to erythro-11-aminomefloquine MQ-53. The aminoazide MQ-51 was also efficiently benzylated with benzyl bromide or methylated under the Eschweiler-Clarke conditions. However, too basic conditions in the Schotten-Bauman reaction caused epimerization at position 11. Identical products MQ-54-55 were obtained from the Mitsunobu reaction of $\mathrm{N}$-alkyl erythro-mefloquines (MQ-20 and MQ-25) with an azide source. Retention of configuration is consistent with the aziridinium ion participation. The azides MQ-54-55 were hydrogenated to obtain the corresponding amines MQ-56-57 [21].
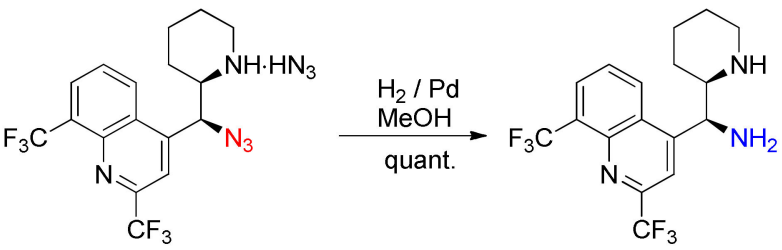

MQ-51· $\mathrm{HN}_{3}$

MQ-53

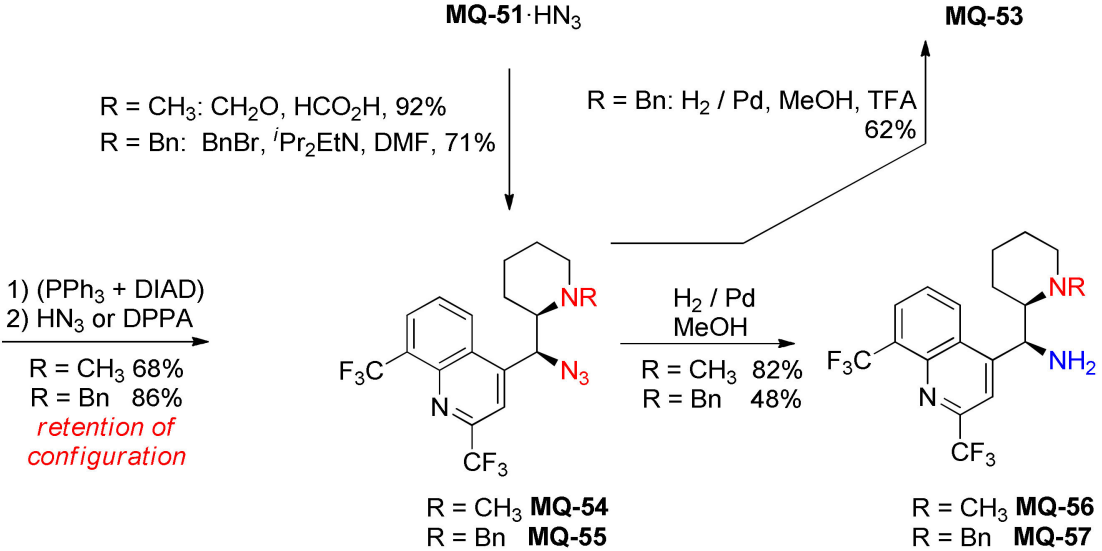


Consequently, the threo isomer of 13-benzyl mefloquine (MQ-58) gave threo-azide MQ-59. The formed derivative was hydrogenated to afford the primary-tertiary amine MQ-60, which is reminiscent of epi-9-aminocinchona alkaloids. Removal of the benzyl group was performed by hydrogenation in acidic solutions [21].<smiles>O[C@H](c1cc(C(F)(F)F)nc2c(C(F)(F)F)cccc12)[C@H]1CCCCN1</smiles>

threo-mefloquine (MQ-8)

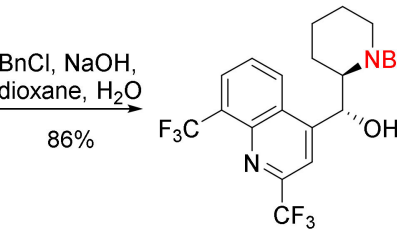

MQ-58

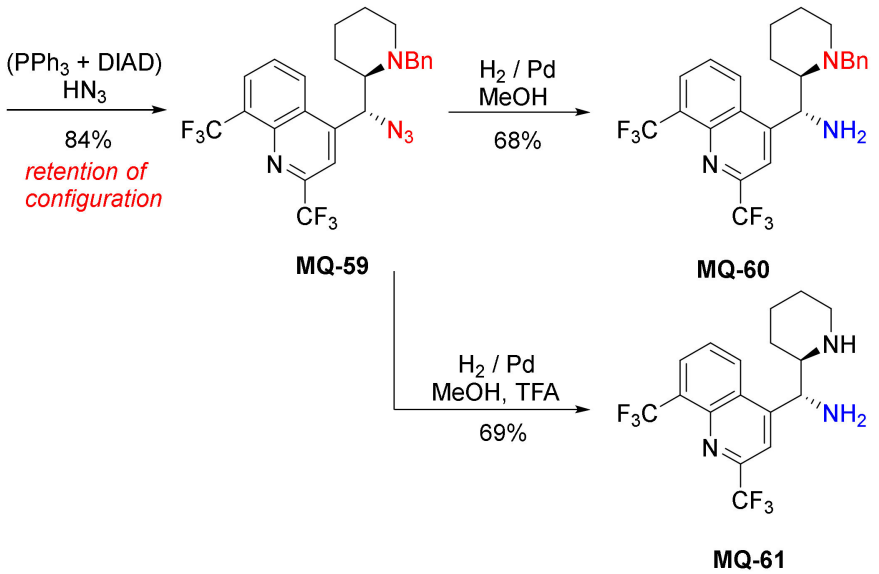

MQ-61

Since the replacement of the hydroxy group for a primary amino group in quinine afforded a potent asymmetric organocatalyst, the aminomefloquine derivatives were assayed for the catalytic activity. Indeed, (+)-erythro-11-aminomefloquine MQ-53 was proven as a better catalyst than 9-epi-aminoquinine in the asymmetric Michael Addition of nitromethane to cyclohexanone in terms of enantioselectivity, delivering the catalytic product with a very good ee (93\%) and a moderate yield [21].

\subsubsection{Imidazolidine Ring}

Mefloquine derivatives with a fused imidazolidinone ring were prepared in the reaction of 11-aminomefloquines MQ-53 and MQ-61 with 1,1'-carbonyldiimidazole (CDI) or phosgene in moderate yields. The products MQ-62-63 were obtained to assist with the assignment of the relative configuration of the initial 11-aminomefloquines [21].

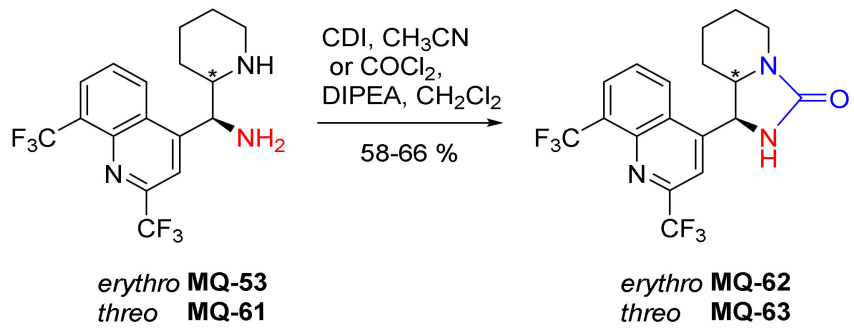

\subsubsection{Oxazolidine Ring}

A library of products with a fused oxazolidine ring were obtained by treating mefloquine with various carbonyl compounds. The reaction was performed mostly with benzaldehyde derivatives in refluxing toluene, while liberated water was azeotropically removed. In the product, a new stereogenic center is formed the oxazolidine carbon atom 2 , and due to the fusion of oxazolidine and piperidine rings, the molecules are more rigid, which generates an additional stereogenic center at the piperidinyl nitrogen atom [68]. The reaction of mefloquine and acetone in the presence of the acidic catalyst resulted in a fusion of 2,2-dimethyl-oxazolidine ring, confirmed by X-ray [69]. The products MQ-64a-q (stereoisomer mixtures) were tested in the anti-TB assay (against $M$. tuberculosis ATCC 27294). A wide variety of substituents provided information on the structure-activity relationship (SAR) for the introduced aromatic ring. It turned out that electron-donating groups such as -OH and -OMe increase the anti-TB potential [68]. Further development indicated that derivatives with a 2-methoxyphenyl MQ-64f, 2,3-dimethoxyphenyl MQ-64h, and 5-nitrothien-2-yl MQ-64o substituents (MIC ca. $12 \mu \mathrm{M}$ ) were more active than meflo- 


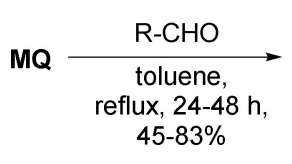

MQ $\underset{\text { reflux, } 3 \mathrm{~h},}{\stackrel{\text { acetone, }}{\text { salicylic acid }}}$<smiles></smiles>

erythro-mefloquine (MQ)<smiles>O[C@H](c1cc(C(F)(F)F)nc2c(C(F)(F)F)cccc12)C1CCCCN1</smiles>

threo-mefloquine (MQ-8) quine, and their activity was similar to ethambutol (MIC $=33$ and $16 \mu \mathrm{M}$, respectively). No cytotoxicity to normal cells was observed [68,70]. A similar set of compounds was tested for antiproliferative activity. It was determined that derivatives with electron-rich aryl and heteroaryl substituents were more cytotoxic against cancer cells such as ovarium cancer, leukemia, and glioblastoma cells compared to mefloquine [71].<smiles>[R]C1OC(c2cc(C(F)(F)F)nc3c(C(F)(F)F)cccc23)C2CCCCN12</smiles>

$M Q-64 a-q$<smiles>CC(C)(C)c1cc(C2OC(C)(C)N3CCCCC23)c2cccc(C(F)(F)F)c2n1</smiles><smiles>[R]=[C]C(C)c1ccccc1</smiles>

$\mathrm{R}^{\prime}=\mathrm{H}, \mathrm{F}, \mathrm{Cl}, \mathrm{Br}, \mathrm{OH}, \mathrm{OCH}_{3}, \mathrm{NO}_{2}$

MQ-64a-g<smiles>COc1cccc(I)c1OC</smiles>

MQ-64h<smiles>COc1cc(I)cc(OC)c1OC</smiles>

MQ-64i<smiles>[R][I-]c1ccccc1</smiles>

2,$3 ; 2,4 ; 2,6 ; 3,4$
$\mathrm{R}=$<smiles>ICCc1ccc(I)cc1</smiles>

MQ-64n<smiles>[R][I-]c1ccc([N+](=O)[O-])s1</smiles><smiles>[O][I+2]O[N+](=O)[O-]</smiles><smiles>[R][I-]I1C=CN=C1I</smiles>

MQ-64q
Another set of derivatives obtained from erythro- and threo-mefloquine was described in a patent as a part of the human adenosine $\mathrm{A}_{2 \mathrm{~A}}$ receptor antagonists. The cyclic products MQ-66a-b were obtained by treating erythro-mefloquine with formaldehyde to give oxazolidines in fair to good yields. The reaction with CDI gave oxazolidinones MQ-67a-b in a rather poor yield [65].

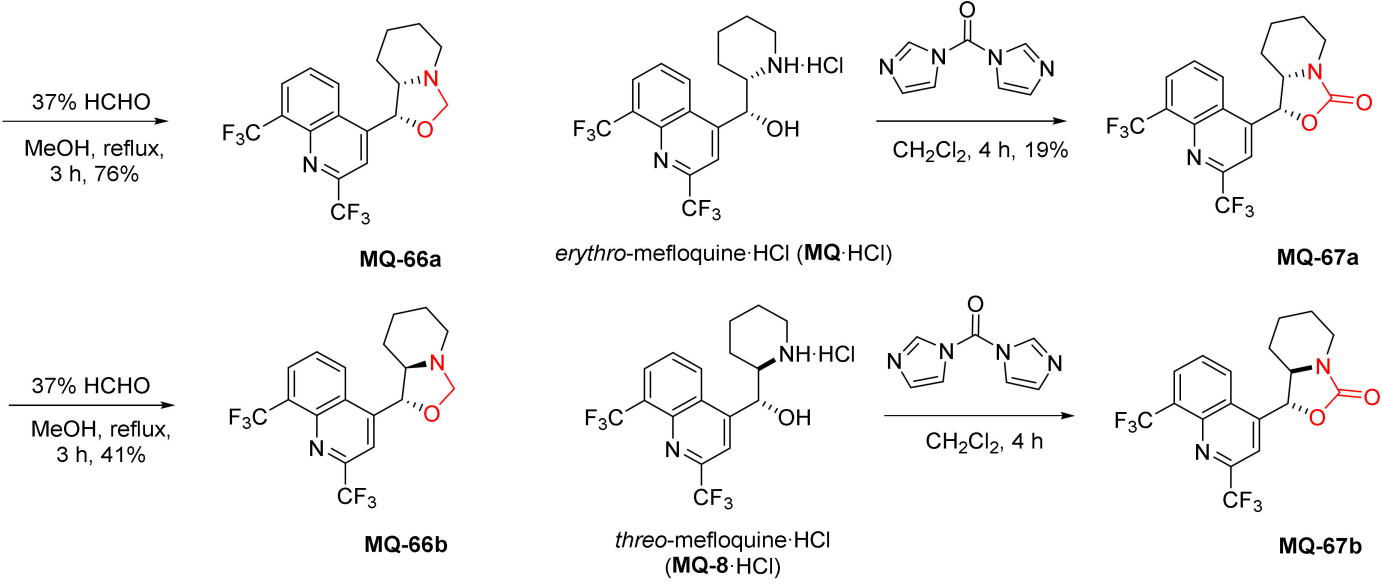

A similar reaction was reported in the literature to give the sulfur analo MQ-68. Fused oxazolidinethione ring was obtained in the reaction of mefloquine with 1,1'-thiocarbonyldii midazole (TCDI) in the presence of triethylamine. Again, the reaction resulted in a rather poor yield. The product did not display anticipated anti-TB activity [40].

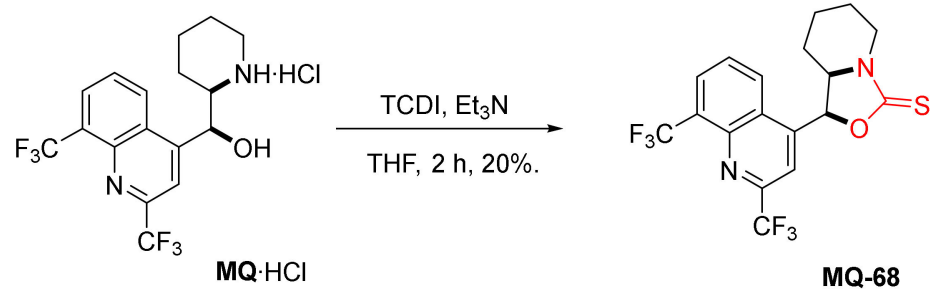




\subsubsection{Oxazaborolidine Ring}

Wardell et al. prepared solvates of racemic erythro-mefloquinium tetraphenylborate, which upon heating above their melting points gave mefloquine- $\mathrm{N}, \mathrm{O}$-diorganoborinate ester MQ-69. The compound is characterized by hydrolytic stability due to the intramolecular $\mathrm{N}-\mathrm{B}$ coordination bond. The alternative single-step process in solution turned out to be less effective. On the other hand, the attempted reaction with sodium tetraethylborate failed due to decomposition. The MIC values from in vitro assays against $M$. tuberculosis for mefloquinium tetraphenylborate and the mefloquine oxazaborolidine derivative MQ-69. EtOH were 12 and $50 \mu \mathrm{g} / \mathrm{mL}$, respectively. The former was presented to be slightly more active than mefloquine hydrochloride $(25 \mu \mathrm{g} / \mathrm{mL})$, yet worse than ethambutol or rifampicin $(2-3 \mu \mathrm{g} / \mathrm{mL})[72]$.
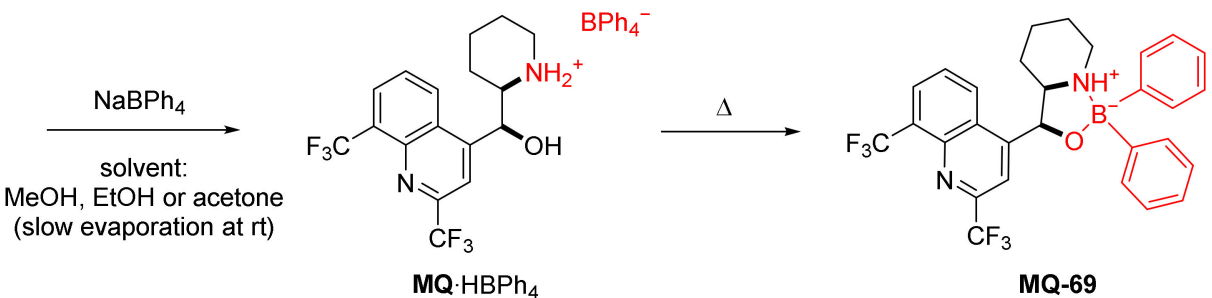

\subsubsection{Morpholine Ring}

The fusion of a six-membered ring involving mefloquine oxygen 11 and nitrogen 13 atoms was accomplished in acetylation-alkylation with chloroacetyl chloride. The reaction carried under the Schotten-Bauman conditions delivered the corresponding morpholinone MQ-70. The subsequent reduction with borane afforded the morpholine derivative MQ-71. Both steps were conducted in rather poor yields [65].

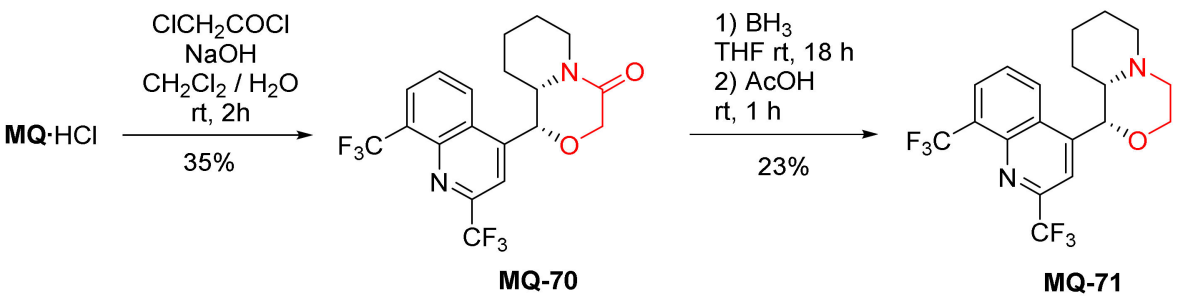

\subsection{Metal Complexes}

From the coordination chemistry perspective, mefloquine possesses three metal binding sites: the nitrogen atoms at position 13 (piperidine) and 1 (quinoline), and the oxygen 11 atom (hydroxy group). The formation of complexes with palladium(II) and platinum(II) was studied. Under neutral conditions, both metal ions formed monodentate complexes with the piperidine nitrogen atom. Deprotonation of the hydroxy group, either spontaneous ( 3 days reaction time) or caused by external base, resulted in bidentate N,O-complexes (Figure 3). Protonated mefloquine species formed a coordination bond only with platinum(II). Based on spectroscopic experiments, it was postulated that the quinoline nitrogen 1 atom was involved [73].

Plasmodium species feed on hemoglobin in erythrocytes. In the process, heme is formed, which is toxic for the pathogen. In order to remove it, the parasite metabolizes it to $\alpha$-hematin and eventually to hemozoin ( $\beta$-hematin) by means of biocrystallization [74]. This process is inhibited by quinine, which forms a coordination bond with protoporphyrin IX [75]. A similar study was performed with mefloquine. Binding constants were similar for $\mathbf{M Q}$ and quinine or quinidine, however, under the studied conditions, no coordination compound with CQ was observed. The adequate crystalline complex of $\mathbf{M Q}$ was obtained from the acetonitrile solution (Figure 4). The coordination bond with iron involves the deprotonated hydroxy group, similarly to Cinchona alkaloids. Additionally, ionization of carboxylic acid 
and piperidine, as well as $\pi$-stacking interactions were observed between the mefloquine and protoporphyrin parts. Minor differences in the activity between $(+)$ and $(-)$-mefloquine were attributed to different abilities to bond to iron(III) protoporphyrin IX [76].

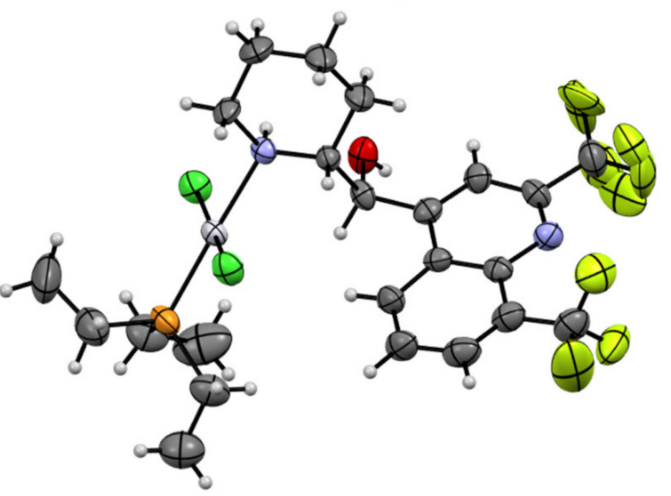

(a)

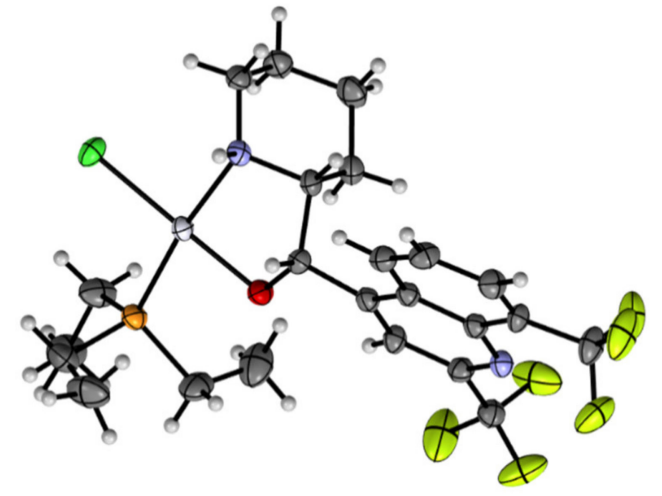

(b)

Figure 3. X-ray structures of chloro(triethylphosphine)platinum(II) complexes with $\mathbf{M Q}$ as mono (a) and bidentate ligand (b) [73].

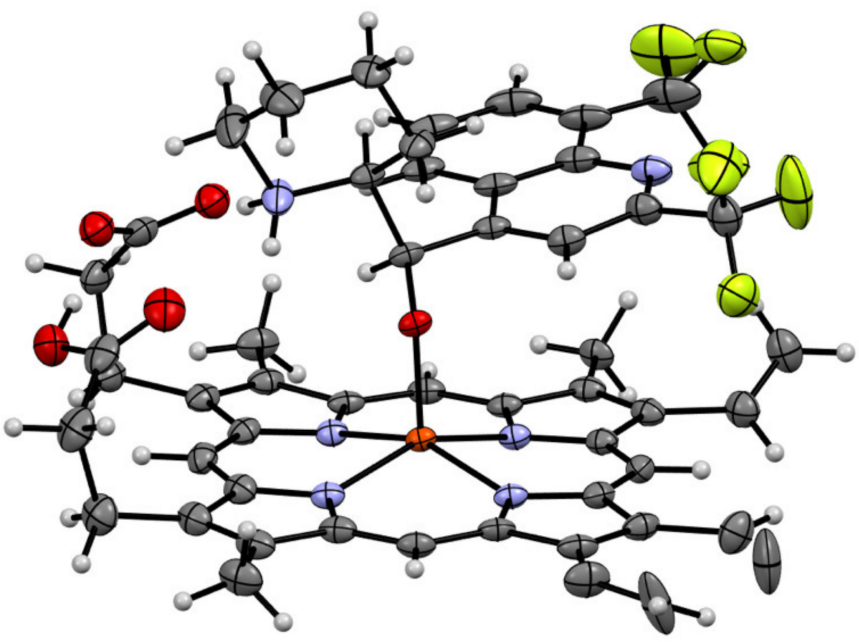

Figure 4. Partial view of X-ray structure of mefloquine complex with Fe(III) protoporphyrin IX [76].

\section{3. (Hydroxy)Chloroquine}

Chloroquine (CQ) was first synthesized in the 1930s as an antimalarial agent. It is obtained in a convergent synthesis, in which aliphatic (novaldiamine, 2-amino-5-dimethylami nopentane) and quinoline parts (4,7-dichloroquinoline) are combined in the final step of the aromatic nucleophilic displacement. Both reactants are available at a low price (ca. 1 \$US/g). Nevertheless, 4,7-dichloroquinoline can be prepared in a three-step sequence. First, Conrad-Limpach condensation between $m$-chloroaniline and diethyl oxalacetate yields 7chloro-4-hydroxyquinoline-2-carboxylic acid ethyl ester. Basic hydrolysis and decarboxylation afford 7-chloro-4-hydroxyquinoline, in which the hydroxy group is exchanged for chlorine by the action of phosphoryl chloride. Final coupling with adequate primary-tertiary diamine produces chloroquine $[77,78]$ or hydroxychloroquine [79] (Scheme 2). 


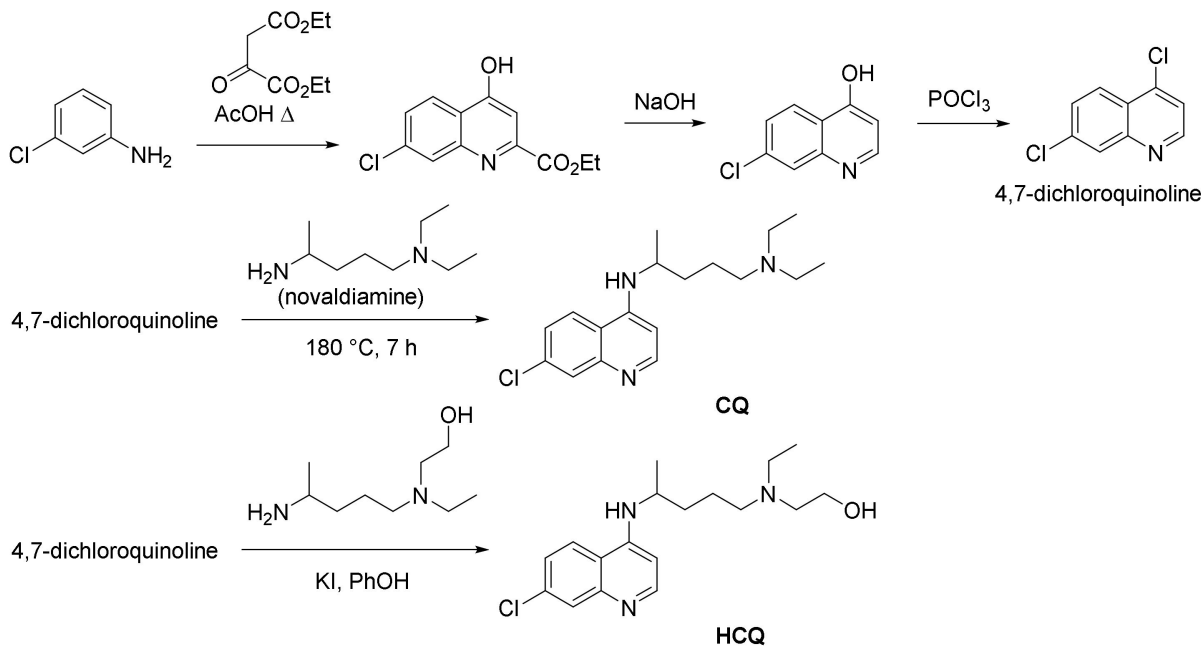

Scheme 2. Synthesis of chloroquine and hydroxychloroquine.

Hydroxychloroquine (HCQ), in which one of the ethyl groups of $\mathbf{C Q}$ was replaced with the hydroxyethyl group, has been developed as a medicine that is safer and related to fewer side effects [80]. The use of CQ and HCQ as antimalarials is now limited due to the emerging chloroquine-resistant $P$. falciparum strains. For research purposes, the following strains are often used [81]:

Chloroquine-sensitive: FcB1, PFB, F32, NF-54 (3D7), FC27 (D10), D6, GB4, T9-96, HB3, ITG2F6, GC03, and Thai.

Chloroquine-resistant: K1, FCR3, W2 (W2mef, Dd2) W1a, W1b, FcB1R, E1a, E1b, P1, 7G8, 7G8, and V1 (V1/S).

Both CQ and HCQ display immunomodulatory effects that have been exploited in the management of a number of autoimmune diseases including lupus (systemic lupus erythematosus, SLE) rheumatoid arthritis, Sjörgen's syndrome, and antiphospholipid antibody syndrome [82]. Both compounds display antiviral properties [83], however. high hopes for curing COVID-19 proved immaterial [84].

Racemic chloroquine is sold as diphosphate (e.g., Resochin, Aralen) and sulfate (e.g., Nivaquine). Hydroxychloroquine is marketed as sulfate (e.g., Plaquenil). The drugs are absorbed from the intestinal tract $[82,85]$. Desethylchloroquine is the main metabolite of chloroquine produced by the human hepatic enzymes P450 2C8 and 2D6 [86]. Other products are bisdesethylchloroquine and 7-chloro-4-aminoquinoline [87].<smiles>CCNCCCC(C)Nc1ccnc2cc(Cl)ccc12</smiles><smiles>CC(CCCN)Nc1ccnc2cc(Cl)ccc12</smiles><smiles>Nc1ccnc2cc(Cl)ccc12</smiles>

7-chloro-4aminoquinoline

The reported modifications of the drug molecules include reactions at quinoline and diamine parts. The reactivity of the quinoline ring includes 7-chlorine nucleophilic substitution, electrophilic or radical substitution at position 3, and alkylation at the quinoline nitrogen atom. The side chain reactivity was exploited at both nitrogen atoms. Hydroxychloroquine displays additional reactivity of the primary alcohol, which seems to be an easy target for modification (Figure 5). Nevertheless, few such approaches can be found in the literature. Generally, due to the low complexity of the total synthesis of the drugs and rather limited reactivity of the remaining functional groups, a lot of analogs were de novo synthesized rather than adopting the top-down approach. 

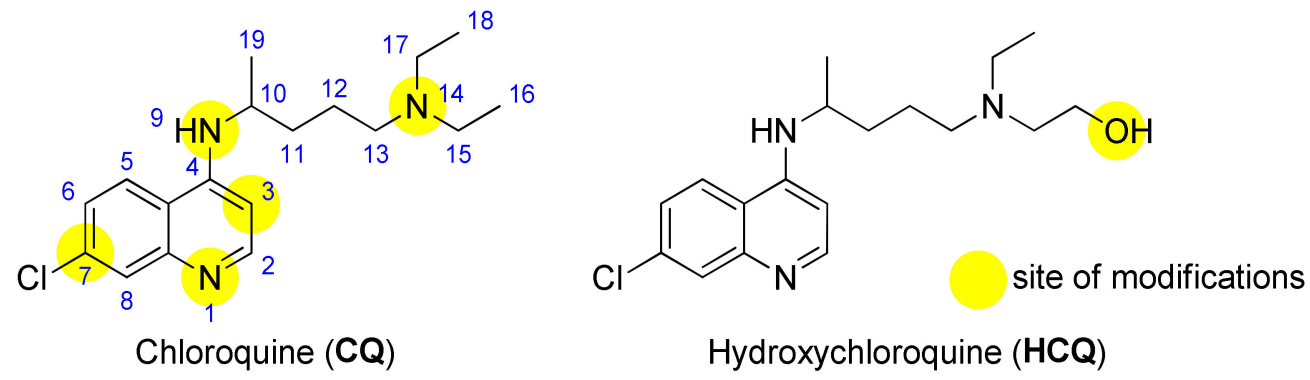

Figure 5. Structure, modification sites, and traditional atom numbering of chloroquine and hydroxychloroquine.

\subsection{Quinoline}

\subsubsection{N-1 Modifications}

Alkylation at the quinoline nitrogen atom was performed in a reaction of chloroquine with a quaternary ammonium salt derived from ferrocene in the presence of $\mathrm{K}_{2} \mathrm{CO}_{3}$. Next, the reaction with L-(+)-tartaric acid caused the exchange of the anion. The product CQ-1 exhibited lower antimalarial activity than the starting material in respect to every tested P. falciparum strain by up to an order of magnitude. It was implied that the compound lost the activity due to quaternization, preventing interactions with heme [88].
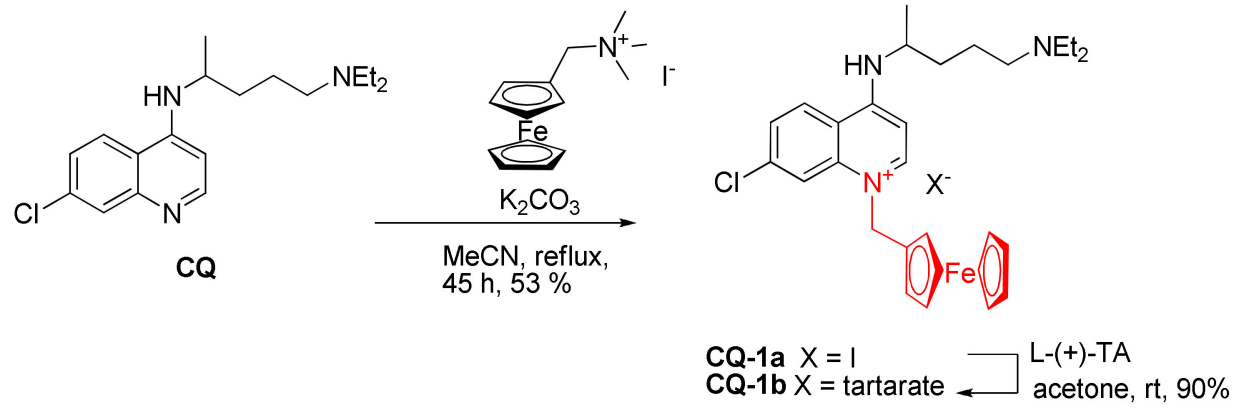

\subsubsection{C-3 Modifications}

Chloroquine undergoes radical iodination at position 3 of the quinoline ring when treated with $\mathrm{N}$-iodosuccinimide and trifluoroperoxyacetic acid. This modification decreased the antimalarial activity of CQ-2 against $P$. falciparum (3D7, D10, Dd2, K1) by at least an order of magnitude compared to unmodified CQ. However, the synergistic effect of both compounds was observed [89].

Electrophilic substitution with tritium $\left({ }^{3} \mathrm{H}\right)$ at position 3 was performed on chloroquine. For the reaction, fluorinated sulfonic acid catalyst supported on a polymer was effective, unlike some other Lewis $\left(\mathrm{AlCl}_{3}\right)$ and weaker Bronsted acids (TFA). In the reaction, all chloroquine (CQ and CQ-3) was recovered [90]. Tritium labeling was conducted to help examine metabolic and excretory pathways.
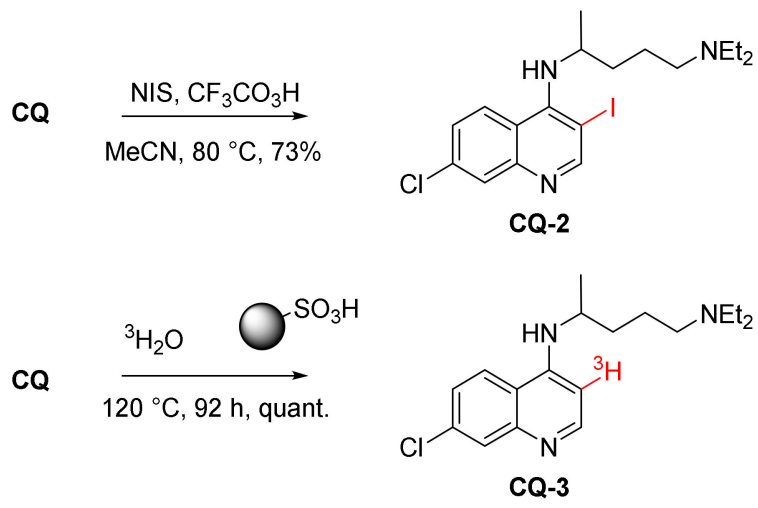


\subsubsection{C-7 Modifications}

Susceptibility of chloroquinoline unit to the nucleophilic aromatic substitution at position 7 was exploited in the reactions with thioureas. This way, a series of 7-dechloro7-thiourea derivatives was obtained. The thiourea CQ-4a with a free $\mathrm{NH}_{2}$ group was further reacted with a few isothiocyanates providing dithiobiurets CQ-5a-e in fair to good yields [91].

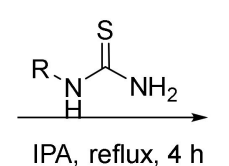

$67 \%$

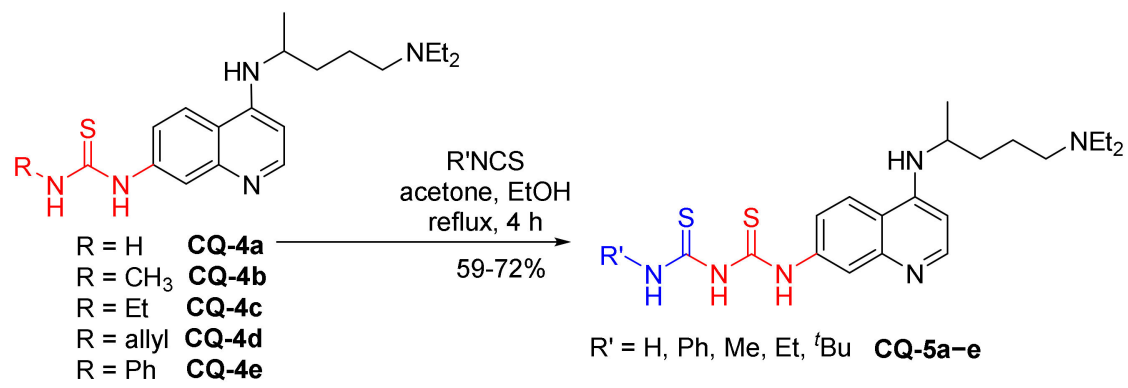

Lipshutz et al. developed a selective nickel-catalyzed method for the reduction of aryl halides. One of the substrates studied in this process was chloroquine, which was hydrodehalogenated at position 7 to give CQ-6 in a quantitative yield [92].

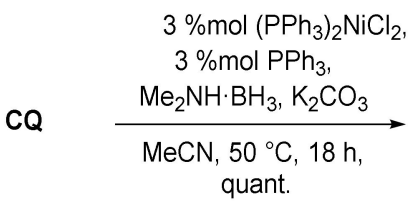

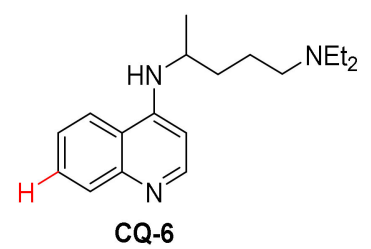

A similar reaction was performed with catalytic palladium $N$-heterocyclic carbene complex. With $\alpha$-deuteriobenzhydrol as a stoichiometric reductant, the reaction proceeded in an excellent yield and resulted in 99\% incorporation of deuterium [93].

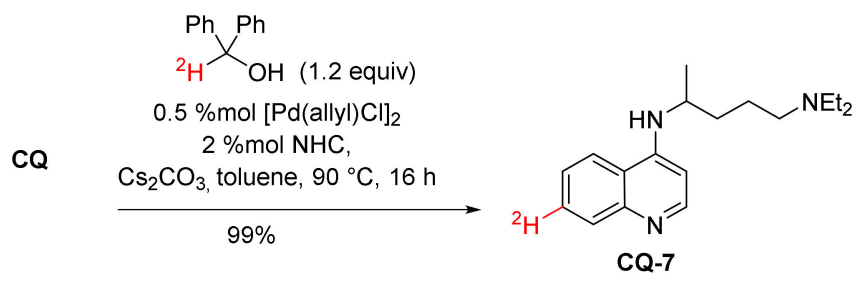

\subsection{Aminoalkyl Part}

\subsubsection{Secondary Amino Group}

A set of carbamates decorated with bisphosphonate units was obtained from chloroquine. First, selected primary alcohols were treated with diphosgene to form reactive chloroformates. Then, reaction with either chloroquine or hydroxychloroquine gave the corresponding carbamates. In the last step, phosphonic esters were hydrolyzed to form bisphosphonic acid derivatives including CQ-8 [94]. The compounds received in this way were assessed for the treatment of myeloma multiplex, a type of cancer in which delivery of the drug to bone is important. The bisphosphonate fragment helped to accumulate the drug in bones, where it could effectively prevent bone loss by killing myeloma cells. The compound CQ-8 and the analogous HCQ derivative showed 70\% killing of CD138 ${ }^{+}$ myeloma cells, while a corresponding conjugate of bortezomib (a drug used to treat multiple myeloma) killed $65 \%$ of the cells. Additionally, the combined therapy with both conjugates was shown to kill $90 \%$ of the cells [95]. 


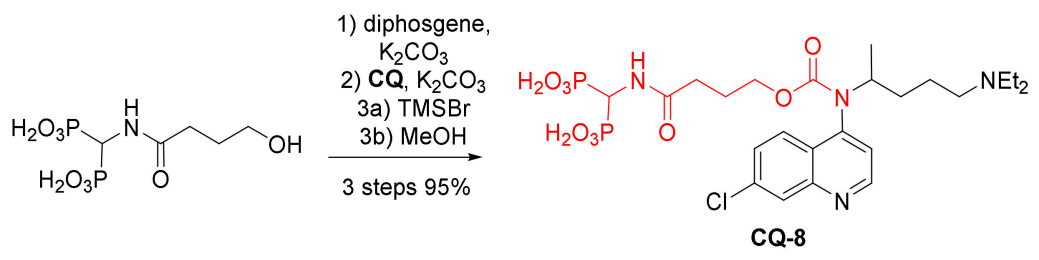

Amides were likely formed in the process of immobilizing chloroquine on gold nanoparticles. Carboxylic acid-coated nanoparticles were obtained by $\mathrm{NaBH}_{4}$ reduction of gold(III) chloride in the presence of 11-mercaptoundecanoic acid. Final coupling was performed using the carbodiimide method with EDC/N-hydroxysuccinimide resulting in an estimated $79 \%$ bonding. The conjugates were shown to interact with serum albumin [96], as well as presented some cytotoxicity against the MCF-7 tumor cell line by induction of autophagy. $\mathbf{C Q}$ was released from the nanoparticle at low $\mathrm{pH}$ [97].

\subsubsection{Tertiary Amino Group}

Reactivity of the tertiary alkyl amine at position 14 was exploited in few reactions. Chloroquine was very efficiently and chemoselectively transformed into the corresponding hydrazinium salt CQ-9. The reaction relied on in situ generated iodonitrene intermediate from ammonium carbamate as a nitrogen source and iodosylbenzene as an oxidant [98].

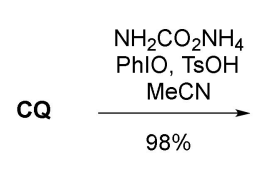<smiles>CC[N+](CC)(CCCC(C)Nc1ccnc2cc(Cl)ccc12)NC(=O)[O-]</smiles>

The application of 2,2,2-trichloroethyl chloroformate [99] to the two-step dealkylation of $C Q$ resulted in rather efficient removal of one of the ethyl groups. Additional annulation product CQ-10 was obtained from the reaction mixture [100]. Desethylchloroquine (CQ-12) was previously de novo synthesized in many steps [101].

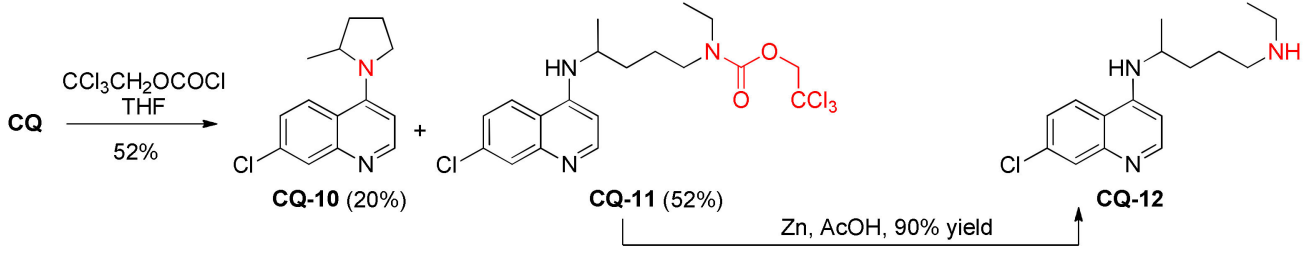

\subsubsection{Photochemical Degradation}

A series of photochemical experiments was performed on CQ. Solutions of the drug were irradiated (240-600 nm), and seven products were identified. Two structures (CQ-12 and CQ-13) are well-known metabolic products in vivo. In every product, the chlorine atom at C-7 was retained, even if the side chain was cleaved [102]. The same pattern was observed with hydroxychloroquine [46]. However, photodechlorination was possible under aerobic conditions [103]. Photochemical degradation of both chloroquine and hydroxychloroquine also produced the dimerization product CQ-14 [46,104].

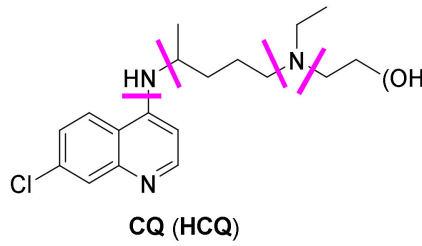

CQ (HCQ) $\mathrm{h} v$

IPA or $\mathrm{H}_{2} \mathrm{O}$

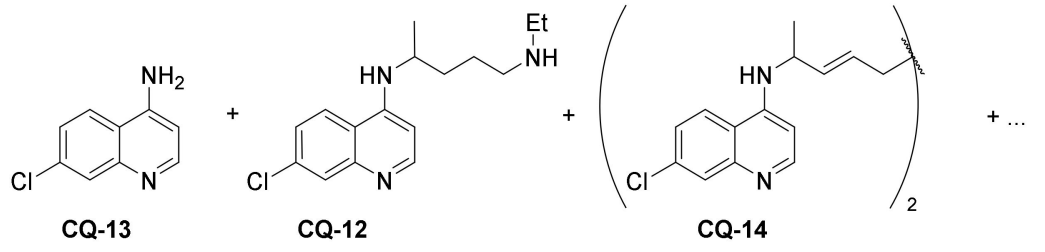




\subsection{Reactions of Primary Alcohol Group of Hydroxychloroquine}

\subsubsection{Etherification}

A chemoselective oxa-Michael addition of HCQ hydroxy group to $\alpha, \beta$-unsaturated sulfonyl and acryl ester was developed. The processes were catalyzed by silver diphosphine complex, a soft Lewis acid, and alkaline metals hexamethyldisilazanamides (HMDS) and Brønsted bases. In the reaction, the remaining amino groups did not react. The addition of HCQ to vinylsylfonamide gave sulfonamide ether CQ-15 in an excellent yield [105], while the reaction with tert-butyl acrylate gave ester ether CQ-16 in a rather poor yield [106].<smiles>CCN(CCO)CCCC(C)Nc1ccnc2cc(Cl)ccc12</smiles>

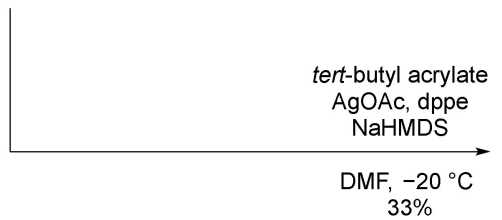

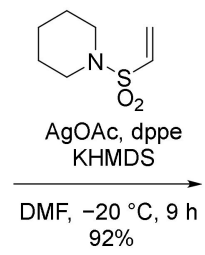<smiles>CCN(CCCC(C)Nc1ccnc2cc(Cl)ccc12)CCOCC[Sn](O)(O)N1CCCCC1</smiles>

CQ-15<smiles>CCN(CCCC(C)Nc1ccnc2cc(Cl)ccc12)CCOCCC(=O)OCc1ccccc1</smiles>

\subsubsection{Esterification}

A few nonsteroidal anti-inflammatory drugs (NSAIDs) having carboxylic acid moiety were activated with carbonyldiimidazole and reacted with $\mathrm{HCQ}$ to yield corresponding esters CQ-17a-f in good yields. Both components are used separately in the treatment and management of rheumatoid arthritis and rely on different therapeutic mechanisms. The authors addressed problems with the unfavorable pharmacologic profile of $\mathbf{H C Q}$ and the side effects of NSAIDs in the gastric track by making a hydrolyzable link in the double prodrugs CQ-17a-f. The products did not undergo hydrolysis in the stomach ( $\mathrm{pH} 1.2)$ but in the intestine (phosphate buffer $\mathrm{pH}$ 7.4). In terms of therapeutic activity, aceclofenac CQ-17c and licofelone CQ-17e prodrugs displayed the most promising anti-inflammatory response [107].
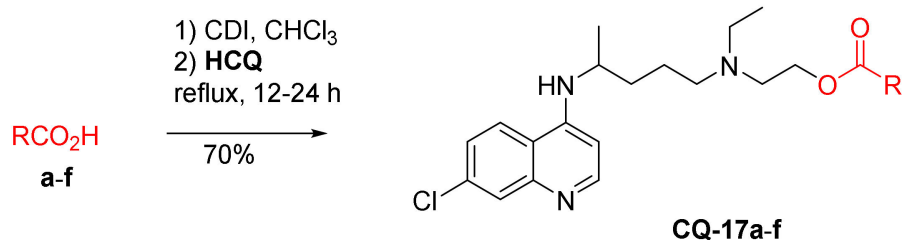

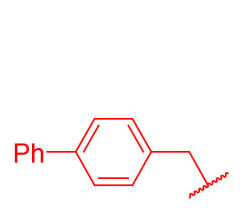

a: bifenylacetic acid

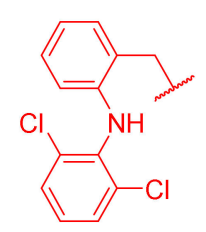

b: diclofenac

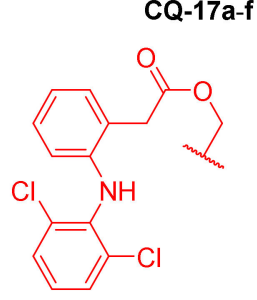

c: aceclofenac

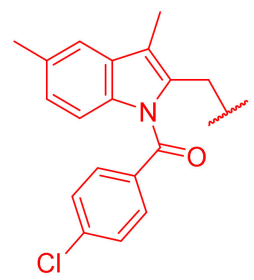

d: indometacin

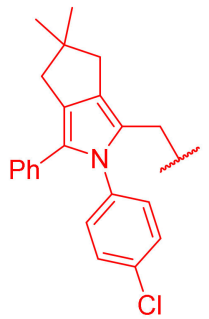

e: licofelone

The carbodiimide method was used to produce the ester of hydroxychloroquine with hexanoic acid derivative of menadione in a fair yield. The acid is a potent glutathione reductase (GR) inhibitor $\left(E_{50} 3.5 \mu \mathrm{M}\right)$. This enzyme is indirectly responsible for the resistance of $P$. falciparum to chloroquine. The enzyme increases the intracellular concentration of glutathione, which in turn protects malaria parasites from oxidative stress and stimulates heme catabolism. The conjugate drug CQ-18 was nearly 2.5 times more active against $P$. falciparum FCB1R than unmodified HCQ with ED 50 values of 107 and $259 \mathrm{nM}$, respectively [108]. 


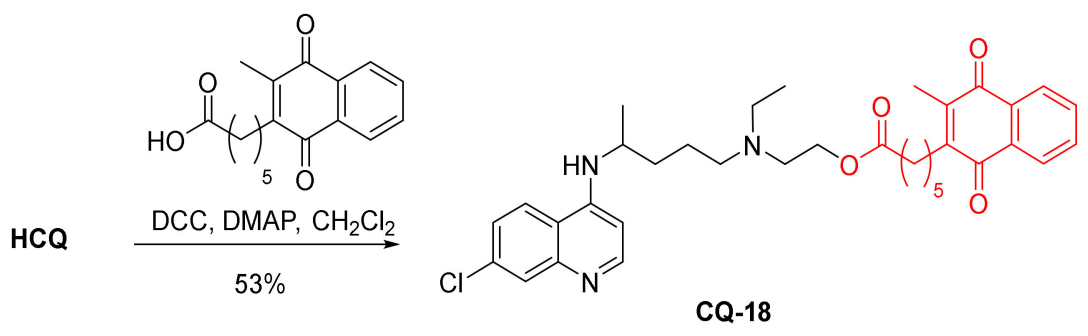

Oshima and coworkers developed a highly chemoselective transesterification method using $\mu$-oxo-dinuclear iron(III) salen catalyst. One of the examples of alcohols was hydroxychloroquine, which gave the corresponding benzoate CQ-19 in a very good yield [109].

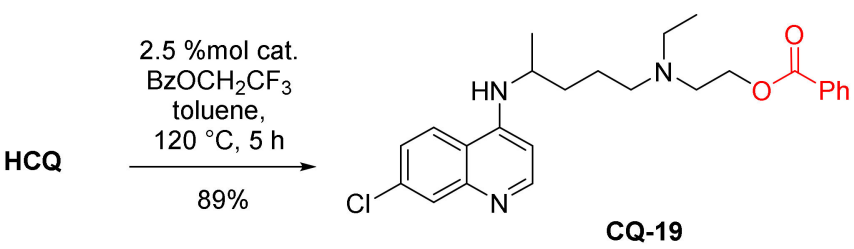

CQ-19

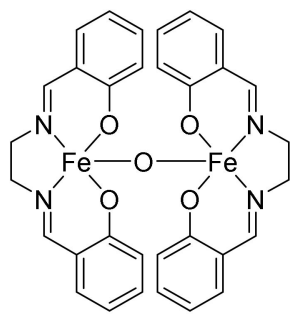

cat.

The hydroxy group of HCQ was also substituted for the amino group in a two-step process. First, hydroxychloroquine was converted to the chloroderivative CQ-20 in the reaction with $\mathrm{SOCl}_{2}$. The chloroderivative $\mathrm{CQ-20}$ was treated either with ammonia in alcohol to form the primary amine CQ-21 or with two small ring primary amines with another hidden amino group (3-amino-1-Boc-azetidine and Boc-bicyclo[1.1.1]pentane-1,3diamine) to form the corresponding secondary amines CQ-22 and CQ-23. Further acylation of the primary amine CQ-21 was performed using uronium salt activation $\left(N, N, N^{\prime}, N^{\prime}\right.$ tetramethyl-O-(benzotriazol-1-yl)uronium tetrafluoroborate, TBTU). Coupling partners acids with fluorinated and heterocyclic parts were used to give corresponding amides CQ-24-25 in good yields [110].

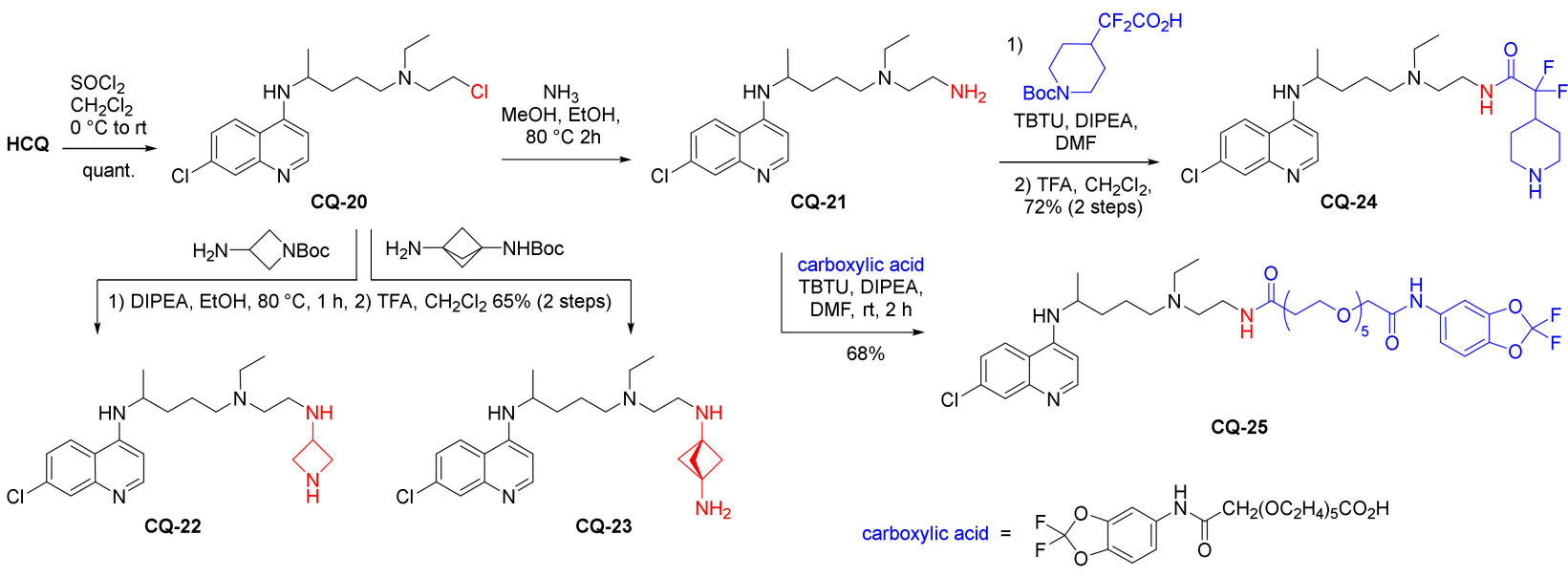

The introduced piperidine fragment in compound CQ-24 was transformed in alkylation or acylation reactions into three further modified products CQ-26-28 in 65-80\% yields. The compounds were screened in the antiviral assay for COVID-19, showing at most marginal activity (5 $\mu \mathrm{M}$ for CQ-27). A more encouraging effect of the compounds CQ-25-28 was found in their interaction with the immune system. All of them inhibited concanavalin A-induced T-cell proliferation and LPS-induced B-cell proliferation, and substantially inhibited cytokine production by these cells. The authors suggested potential for the compounds in the treatment of immune disorders and inflammatory diseases [110]. 
<smiles>CCN(CCCC(C)Nc1ccnc2cc(Cl)ccc12)CCNC(=O)C(F)(F)C1CCN(CC(O)C(F)(F)F)CC1</smiles>

CQ-26<smiles>CCN(CCCC(C)Nc1ccnc2cc(Cl)ccc12)CCNC(=O)C(F)(F)C1CCN(CCOCCOC)CC1</smiles>

CQ-27

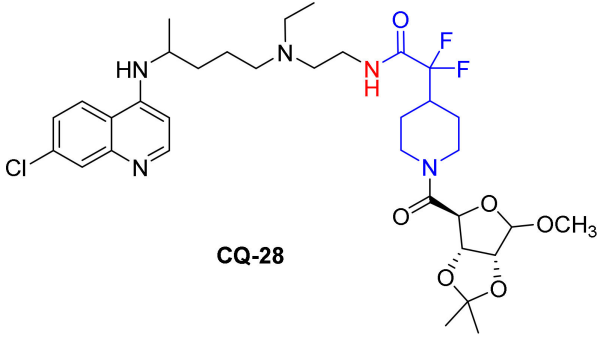

CQ-28

Modified polysaccharides such as hydroxyethyl starch (HES) are characterized by biocompatibility, biodegradability, and low immunogenicity. Therefore, they can be used as drug carriers. Hydroxychloroquine was conjugated to HES with the carbonate linker. In the first step, the active amide CQ-29 was synthesized from HCQ and carbonyldiimidazole in a good yield. The subsequent reaction with HES gave polymeric materials CQ-30 containing $2.4-32 \mathrm{w} \%$ of hydroxychloroquine. The yield was in the $61-82 \%$ range. The preserved secondary amino group was important for binding to the CXCR4 receptor in order to inhibit the spread of tumor cells. The polymer at $1 \mu \mathrm{M}-\mathrm{CQ}$ concentration inhibited pancreatic cancer cell invasion by approximately 80\% (AsPC-1), 70\% (MiaPaca-2), and 10\% (MiaPaca-1). The unmodified drug remained inactive [111].

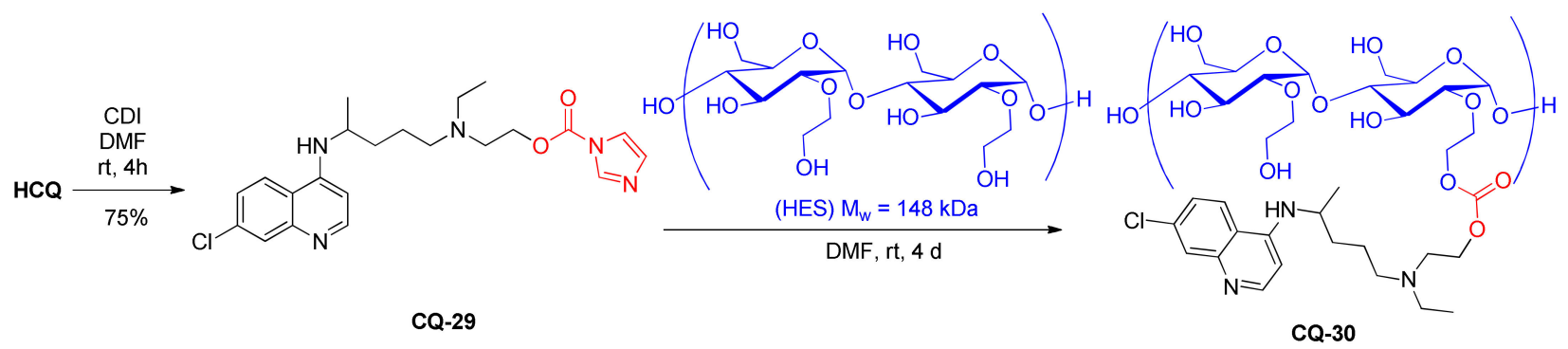

Hydroxychloroquine was used to prepare hydrolyzable and nondegradable methacrylamide copolymers. The reaction of methacryloyl chloride with HCQ gave the corresponding ester CQ-31 in a moderate yield. Radical copolymerization of CQ-31 with $N$ hydroxypropylmethacrylamide (HPMA) gave the polymeric material CQ-32. The polymer had $M_{\mathrm{W}} 34.5 \mathrm{kDa}$, a polydispersity index of 1.1, and $17 \mathrm{~mol} \%$ chloroquine loading [112].<smiles>C=C(C)C(=O)OCCN(CC)CCCC(C)Nc1ccnc2cc(Cl)ccc12</smiles><smiles>C=CCC(C)(C(=O)OCCC(C)C(C)(C)C(=O)NCC(C)O)C(=O)OCCN(CC)CCCC(C)Nc1ccnc2cc(Cl)ccc12</smiles>

The hydroxy group of HCQ was substituted with azide in a Mitsunobu-type reaction with diphenylphosphorylazide and DBU (Merck method). The obtained azide CQ-33 underwent copper(I)-catalyzed alkyne-azide 1,3-dipolar 'click' cycloaddition (CuAAC) with alkynes. The reaction with the $N$-propargyl-methacrylamide monomer gave the corresponding triazole CQ-34. Further RAFT copolymerization of CQ-34 with HPMA produced the polymeric material CQ-35A. A similar product (CQ-35B) was produced in CuAAC of CQ-33 with a polymethacrylamide polymer decorated with terminal alkyne groups. The polymers had comparable $M_{\mathrm{W}} 20.3$ and $21.4 \mathrm{kDa}$, while the polydispersity index was 1.1 and 1.2, and chloroquine loading was 13.5 and $17.4 \mathrm{~mol} \%$ for CQ-35A and 
CQ-35B, respectively. Both CQ-32 and CQ-35A/B exhibited increased inhibition of 4T1 breast cancer cell migration in comparison with HCQ. The migration was decreased by $49 \%$ (CQ-35A), 51\% (CQ-35B), and 56\% (CQ-32), which proved that the effect can be obtained without chloroquine release and that the triazole ring did not interfere with the anticancer activity. The polymeric drugs also exhibited favorable cytotoxicities [112-114].

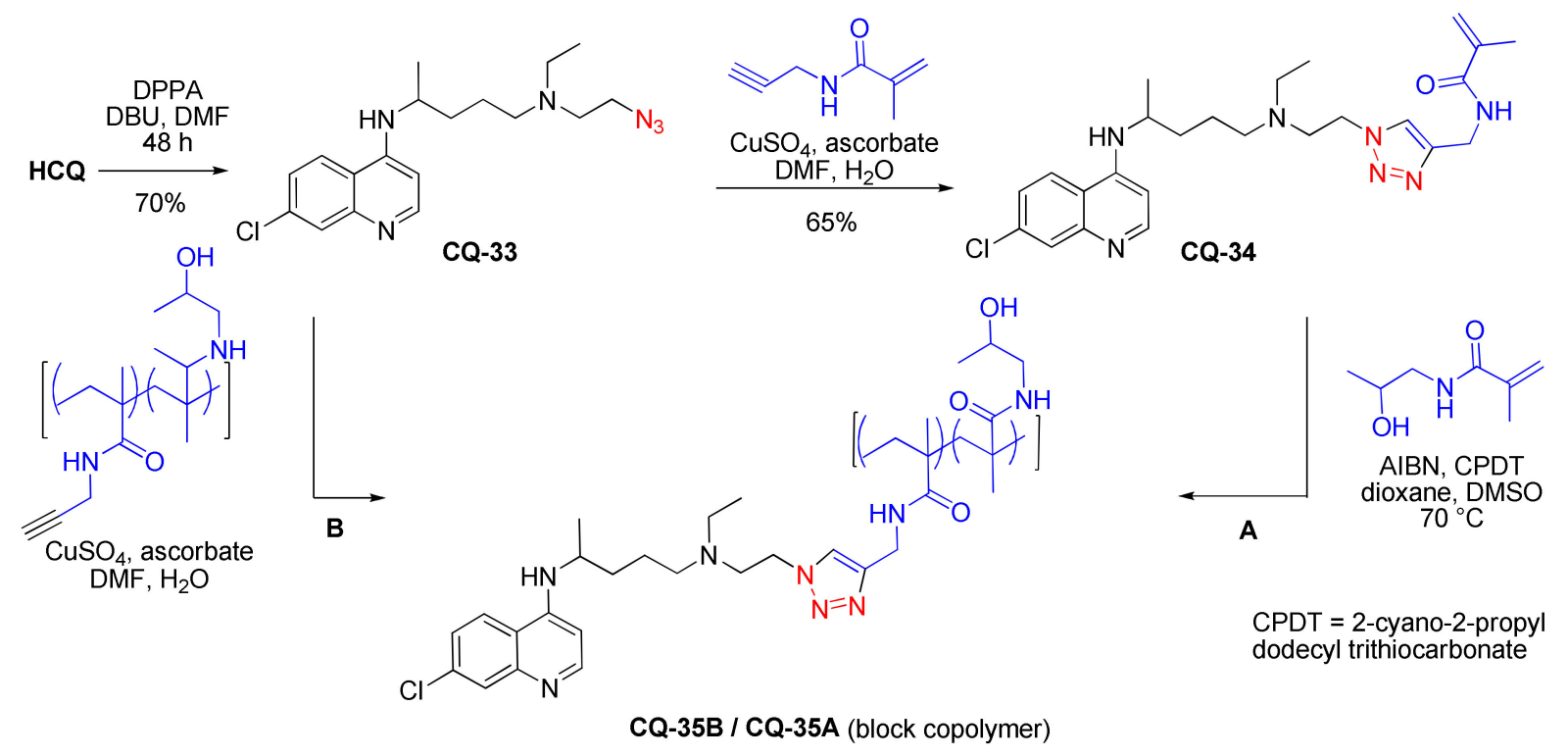

Multicomponent conjugates containing both gold nanoparticles, siRNA, PEG, and hydroxychloroquine were reported. The link between gold and HCQ was made by esterification of complexed citrate under carbodiimide activation. Hydroxychloroquine was found to improve transfection of cells by the RNA and accumulation of nanoparticles in endosomes [115].

\subsubsection{Miscellaneous}

The electrochemical oxidative process, in which the hydroxy group of HCQ was probably oxidized to an aldehyde, was developed for analytical purposes. With multi-walled carbon nanotube-modified carbon paste electrode (MWCNTs/CPE) in the adsorptive stripping, differential pulse voltammetry nanomolar concentrations of pharmaceuticals in blood serum were determined [116].

\subsection{Metal Complexes}

There are a few known isolated coordination compounds of chloroquine with transition metal ions (Table 1).

Chloroquine possesses three nitrogen donor atoms capable of coordinating to a metallic center: the most common quinoline $\mathrm{N}-1$ atom, tertiary alkyl amine $\mathrm{N}-14$, and secondary arylamine $\mathrm{N}-9$. The last one was observed in the complexes of multiply protonated chloroquine. Bidentate coordination has been reported either for two separate metallic centers or in a chelation mode (Figure 6). Moreover, $\eta^{6}$ coordination to the benzene part of quinoline was postulated. Structure elucidation mostly relied on spectroscopic data (e.g., IR, NMR), only in one case X-ray structure provided unambiguous proof (Table 1, entry 1, Figure 7). Some discrepancies between reported coordination modes may exist (Table 1, entry 13). Most development has been made for complexes with gold, platinum, and ruthenium, which display improved antimalarial and antiproliferative properties. 
Table 1. Known isolated coordination compounds of metal ions with chloroquine (CQ) and the established coordination site.

\begin{tabular}{|c|c|c|c|c|}
\hline Entry & Metal & Complex & Site & Reference \\
\hline 1 & Gold(I) & {$\left[\mathrm{Au}\left(\mathrm{PR}_{3}\right) \mathrm{CQ}\right] \mathrm{X}$} & $\mathrm{N} 1^{1}$ & [117-120] \\
\hline 2 & & {$\left[\mathrm{AuCQ}\left(\mathrm{C}_{5} \mathrm{~F}_{5}\right)\right]$} & $\mathrm{N} 1$ & [119] \\
\hline 3 & & {$\left[\mathrm{AuCQ}\left(\mathrm{PQ}^{*}\right)\right] \mathrm{PF}_{6}$} & N1 & [121] \\
\hline 4 & Gold(III) & {$\left[\mathrm{Au}\left(\mathrm{Et}_{2} \mathrm{O}\right) \mathrm{CQ}\left(\mathrm{SR}^{*}\right) \mathrm{Cl}\right] \mathrm{Cl}$} & N14 & [118] \\
\hline 5 & & {$\left[\mathrm{Au}(\mathrm{CQ})_{2}(\mathrm{Cl})_{2}\right] \mathrm{Cl}$} & N14 & [118] \\
\hline 6 & Ruthenium(II) & {$\left[\mathrm{Ru}\left(\right.\right.$ arene $\left.\left.^{*}\right) \mathbf{C Q}(\mathrm{Cl})_{2}\right]$} & N1 & {$[122,123]$} \\
\hline 7 & & {$\left[\mathrm{Ru}\left(\right.\right.$ cymene) $\left.\left(\mathrm{bipy}^{*}\right) \mathrm{CQ}\right]$} & N1 & [124] \\
\hline 8 & & {$\left[\mathrm{Ru}(\right.$ cymene $\left.)\left(\mathrm{CQ} \cdot 2 \mathrm{H}_{3} \mathrm{PO}_{4}\right)\right]\left(\mathrm{BF}_{4}\right)_{2}$} & $\pi$-benzene & [122] \\
\hline 9 & & {$\left[\mathrm{Ru}(\mathbf{C Q})(\mathrm{Cl})_{2}\right]_{2}$} & N1,N14 & [125] \\
\hline 10 & Rhodium(I) & {$[\mathrm{RhCQ}(\mathrm{cod}) \mathrm{Cl}]$} & N1 & [125] \\
\hline 11 & Platinum(II) & cis-[Pt(diphosphine $\left.\left.{ }^{*}\right) \mathrm{CQCl}\right]$ & N1 & [126] \\
\hline 12 & & trans- $\left[\mathrm{Pt}\left(\mathbf{C Q} \cdot 2 \mathrm{H}_{3} \mathrm{PO}_{4}\right)_{2}(\mathrm{X})_{2}\right]$ & N9 & {$[127,128]$} \\
\hline 13 & & trans $-\left[\mathrm{Pt}(\mathrm{CQ})_{2}(\mathrm{X})_{2}\right]$ & N14 or N1 & {$[127,129]$} \\
\hline 14 & Palladium(II) & {$\left[\mathrm{Pd}(\mathrm{CQ})_{2}(\mathrm{X})_{2}\right]$} & N1 & [130] \\
\hline 15 & Iridium(I) & {$[\operatorname{Ir}(\operatorname{cod}) \mathbf{C Q C l}]$} & N1 & [131] \\
\hline 16 & & $\left.[\mathrm{IrCQ} \text { (acetone })_{2}\right] \mathrm{PF}_{6}$ & N9,N14 & [131] \\
\hline 17 & Iridium(III) & $\mathrm{Ir}_{2} \mathrm{Cl}_{6}(\mathrm{CQ})$ & N9,N14 & [131] \\
\hline 18 & Cobalt(III) & {$\left[\mathrm{CoCQ}(\mathrm{en})_{2} \mathrm{Cl}\right] \mathrm{Cl}_{2}$} & N1 & [132] \\
\hline 19 & Vanadium(IV) & {$\left[\mathrm{VO}(\mathrm{acac})_{2}\left(\mathrm{CQ} \cdot \mathrm{H}_{2} \mathrm{SO}_{4}\right)\right]$} & N1 & [133] \\
\hline 20 & Chromium(III) & $\mathrm{Cr}(\mathrm{NO})(\mathrm{CN})_{2}\left(\mathrm{CQ} \cdot 2 \mathrm{H}_{3} \mathrm{PO}_{4}\right)\left(\mathrm{H}_{2} \mathrm{O}\right)$ & N1,N9 & [134] \\
\hline 21 & Zinc(II) & {$\left[\mathrm{ZnCQ}\left(\mathrm{H}_{2} \mathrm{O}\right)(\mathrm{OAc})_{2}\right]_{2}$} & unspecified & [135] \\
\hline 22 & & {$\left[\mathrm{ZnCQ}\left(\mathrm{H}_{2} \mathrm{O}\right)_{2} \mathrm{Cl}_{2}\right]$} & $\mathrm{N} 1$ & [135] \\
\hline 23 & Iron(II) & {$\left[\mathrm{Fe}(\mathrm{CQ})_{2}\left(\mathrm{H}_{2} \mathrm{O}\right)\right] \mathrm{Cl}_{2}$} & $\mathrm{~N} 9, \mathrm{~N} 14^{2}$ & {$[136]^{2}$} \\
\hline 24 & Copper(I) & {$\left[\mathrm{Cu}(\mathbf{C Q})_{2}\right] \mathrm{Cl}$} & N1 & [135] \\
\hline 25 & & {$\left[\mathrm{Cu}\left(\mathrm{PPh}_{3}\right) \mathrm{CQ}\left(\mathrm{NO}_{3}\right)\right]$} & N1 & [135] \\
\hline 26 & Copper(II) & {$\left[\mathrm{CuCQ}(\mathrm{OAc})_{2}\right]_{2}$} & unspecified & [135] \\
\hline 27 & & {$\left[\mathrm{Cu}(\mathrm{CQ})_{2}\left(\mathrm{H}_{2} \mathrm{O}\right)\right] \mathrm{Cl}_{2}$} & N9,N14 2 & {$[136]^{2}$} \\
\hline 28 & Nickel(II) & {$\left[\mathrm{Ni}(\mathrm{CQ})_{2}\left(\mathrm{H}_{2} \mathrm{O}\right)\right] \mathrm{Cl}_{2}$} & N9,N14 ${ }^{2}$ & {$[136]^{2}$} \\
\hline
\end{tabular}

${ }^{1}$ Based on X-ray structure; ${ }^{2}$ limited supporting data; ${ }^{*} \mathrm{SR}=$ tetraacetyl-thioglucose; $\mathrm{PQ}=$ primaquine; arene $=p$-cymene or benzene; acac $=$ acetylacetone; bipy $=2,2^{\prime}$-bipyridine, also: 1,10 -phenanthroline; $\operatorname{cod}=1,4$ cyclooctadiene; diphosphine $=\mathrm{dppp}, \mathrm{dppf}$, also: $2 \times \mathrm{PPh}_{3} ; \mathrm{en}=$ ethylenediamine .<smiles></smiles>

N1 coordination<smiles>[M]CCCC(C)Nc1ccnc2cc(Cl)ccc12</smiles>

N14 coordination<smiles></smiles>

$\mathrm{N} 1, \mathrm{~N} 14$ coordination<smiles>[M]NC(C)CCCN(CC)CC</smiles>

N9 coordination<smiles>CC[M]1N(CC)CCCCN1c1ccnc2cc(Cl)ccc12</smiles>

N9,N14 chelation

Figure 6. Coordination modes of chloroquine.

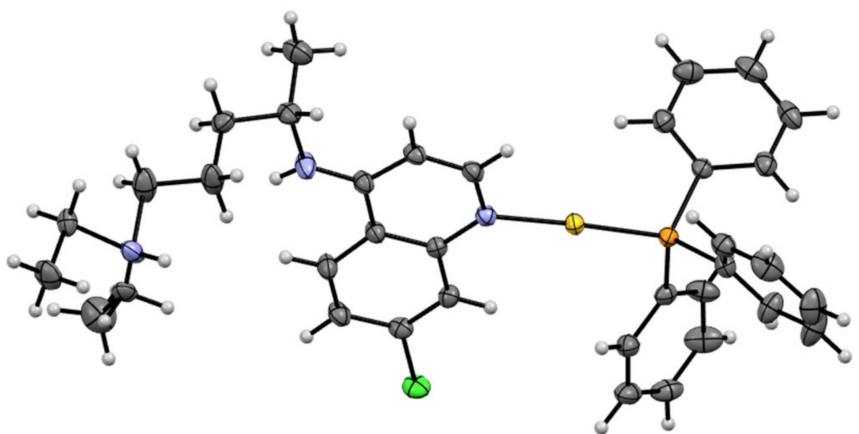

Figure 7. X-ray structure of $\left[\mathrm{Au}\left(\mathrm{PPh}_{3}\right)\left(\right.\right.$ chloroquine- $\left.\left.\mathrm{H}^{+}\right)\right]\left(\mathrm{NO}_{3}\right)_{2}[120]$. 
A few gold complexes of chloroquine were prepared by Navarro and coworkers. Particularly, gold(I) complexes similar to $\left[\mathrm{Au}\left(\mathrm{PPh}_{3}\right) \mathrm{CQ}\right] \mathrm{PF}_{6}$ displayed activity against P. falciparum enhanced by an order of magnitude. For the $\mathrm{FcB}_{\mathrm{C}} 1$ strain, $\mathrm{IC}_{50}$ was reported at $5 \mathrm{nM}$ ( $47 \mathrm{nM}$ for CQ) and for FcB2 strain $23 \mathrm{nM}$ compared to $110 \mathrm{nM}$ for CQ. In vivo study on the P. berghei model revealed lower parasitemia for the treatment with the complex $(7 \%)$ compared to CQ $(25 \%)$ [117]. Later tests revealed that both N-1 coordinated gold(I) and $\mathrm{N}-14$ coordinated gold(III) complexes were active against multiple strains of $P$. falciparum (FcB1, W2, K1, F32) in vitro. The most active was [Au( $\left.\left.\mathrm{PEt}_{3}\right) \mathrm{CQ}\right] \mathrm{PF}_{6}$ [118]. The X-ray structure of a related complex was published (Figure 7) [120]. Gold(I) was also used to tether two antimalarials, chloroquine and primaquine (PQ), into a single molecule. The resulting double drug exhibited higher activity against $P$. falciparum (3D7, W2) in vitro and P. berghei (liver-stage) in vivo than unlinked drugs [121].

Platinum(II) cis-complexes with phosphine ligands presented stronger interaction with DNA and serum albumin (BSA) than the unmodified drug. The bistriphenylphosphinecontaining complex presented moderate cytotoxic activity against a few human tumor cell lines. The $\mathrm{IC}_{50}$ values were in the 5-10 $\mu \mathrm{M}$ range for breast (MDA-MB-231 and MCF-7), lung (A549), and prostate cancer cell lines (DU-145) [126]. Platinum CQ complexes were found to bind with DNA. The nature of interactions was dependent on the complex type, with $\mathrm{N}-14$ coordinate trans- $\left[\mathrm{Pt}(\mathrm{CQ})_{2} \mathrm{Cl}_{2}\right]$ displaying the most covalent character. This complex also displayed a cytostatic effect on multiple cancer cell lines. The growth inhibition, $\mathrm{GI}_{50}$ in the 6-9 $\mu \mathrm{M}$ range, and total growth inhibition at $\leq 19 \mu \mathrm{M}$ were noted for human HT29, LoVo, MCF-7, SKBR-3, PC-3, and murine B16/BL6 [127]. Liposome encapsulation of trans- $\left[\mathrm{Pt}\left(\mathrm{CQ} \cdot \mathrm{H}_{3} \mathrm{PO}_{4}\right)_{2} \mathrm{Cl}_{2}\right]$ was performed [128].

Among complexes of chloroquine and ruthenium, $\left[\mathrm{Ru}(\mathrm{CQ}) \mathrm{Cl}_{2}\right]_{2}$ displayed up to 4-fold increased effectiveness against chloroquine-resistant strains of $P$. falciparum, and P. berghei [125]. On the other hand, the arene diamine complex $\left[\mathrm{Ru}\left(\eta^{6}-p\right.\right.$-cymene $)(4,7-$ diphenyl-1,10-phenanthroline) $\mathrm{CQ}]\left(\mathrm{PF}_{6}\right)_{2}$ was found to interact with DNA and serum albumin, as well as noticeably inhibit tumor cell growth in vitro (A549, MDA-MB-231, MCF-7, L929) with $\mathrm{IC}_{50}$ in the 0.8-6 $\mu \mathrm{M}$ range [124].

Metal organic frameworks (MOF) with incorporated chloroquine were reported. Matrices based on zinc [137], zirconium [138], and titanium [139] were studied for the therapeutic release of $\mathrm{CQ}$ from the material.

\subsection{Noncovalent Compounds}

Supramolecular inclusion complexes of chloroquine with some common host molecules are known. For example, complexes with $\alpha$ - and $\beta$-cyclodextrins [140] and cucurbit [7] uril [141] all displayed 1:1 stoichiometry.

A few attempts were made to identify compounds formed from chloroquine and various porphyrin/heme derivatives relevant to malaria. However, fully conclusive data was not obtained. A study on CQ interactions with ferriprotoporphyrin IX revealed stoichiometry of 1:2 CQ:Fe(III)PPIX, and dimerization via $\mu$-oxo bond [142]. Ferrimesoporphyrin IX of mesohematin anhydride, a synthetic analog of hemozoin, was used to examine the mode of binding of chloroquine. EXAFS experiments indicated the proximity of the iron atom to quinoline $\mathrm{N}-1$ and neighboring carbon atoms of chloroquine [143]. Non-covalent complexes of CQ with urohemin I (2:1 stoichiometry) and uroporphyrin were found in aqueous solutions [144]. Also in the X-ray crystal structure of gallium(III), protoporphyrin IX with CQ (2:2 stoichiometry) ionic and hydrogen-bonding interactions was found rather than covalent coordination links (Figure 8) [145]. 


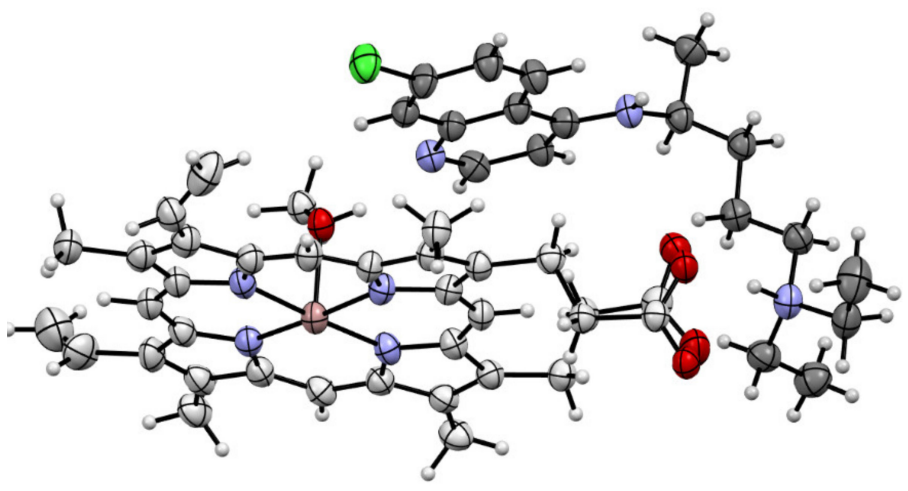

Figure 8. Part of X-ray structure of chloroquine: gallium(III) protoporphyrin IX compound [145].

Chloroquine was used to synthesize graphene oxide conjugates. Although the interactions are noncovalent ( $\pi-\pi$ interactions), there is some FT-IR evidence of binding between the amino group of chloroquine and carbonyl groups of graphene oxide. The nanoconjugates showed an antiproliferative effect on the A549 lung cancer cell line [146].

Chloroquine-containing chitosan-tripolyphosphate (CS-TPP) nanoparticles were prepared in order to investigate their protective effect on the liver in P. berghei NK65 infection. FT-IR spectroscopy indicated conjugation of chloroquine with CS-TPP and red blood cell surface. The chloroquine-loaded nanoparticles show a higher decrease of the apoptotic cells than chloroquine alone (61 vs. 25\%) [147].

\section{Closing Remarks}

The viability of the late-stage modification to the structure of antimalarials seems to be directly related to the difficulty of the de novo synthesis. For example, virtually none of the thousands of derivatives of Cinchona alkaloids were obtained by the total synthesis. In contrast, out of thousands of analogs of chloroquine, just a few described above were prepared from commercially available chloroquine. The modification is more challenging than the synthesis due to the poor reactivity of the remaining groups. Mefloquine is an intermediate case since its synthesis is multistep and somewhat difficult. However, in subsequent modifications, neighboring group participation may be experienced and the stereochemistry requires consideration.

The obtained products were tested in a few different assays, which were outlined in this review, while a summary of available biological data for the covalent derivatives can be found in the Supplementary Table S1. Improved antimalarial potency was found for some gold complexes of $\mathbf{C Q}$ and conjugates with artemisinin. Few compounds were shown to act synergistically with parent drugs, possibly reversing resistance. Immunomodulatory effect of conjugates with anti-inflammatory drugs CQ-17 showed promise in the experimental treatment of arthritis. On the other hand, incorporation of difluoromethylene and heterocyclic parts (CQ-25-28) gave rise to immunosuppressive activity. Conjugation to polymeric carriers (CQ-30-35) inhibited invasion of some cancer cells.

Supplementary Materials: The following supporting information can be downloaded, Table S1. Summary of hydroxy(chloroquine) derivatives and available in vitro and in vivo experimental data.

Author Contributions: Conceptualization, P.J.B.; Investigation, D.J.K. (mefloquine) and M.K.J. (chloroquine); preliminary writing, D.J.K., M.K.J. and P.J.B.; original draft preparation, D.J.K., writingreview and editing, P.J.B. and D.J.K. All authors have read and agreed to the published version of the manuscript.

Funding: This research was funded by National Science Center (NCN, Poland) grant number 2018/30/E/ST5/00242.

Conflicts of Interest: The authors declare no conflict of interest. 


\section{References}

1. Chugh, A.; Kumar, A.; Verma, A.; Kumar, S.; Kumar, P. A Review of Antimalarial Activity of Two or Three Nitrogen Atoms Containing Heterocyclic Compounds. Med. Chem. Res. 2020, 29, 1723-1750. [CrossRef]

2. Gildenhard, M.; Rono, E.K.; Diarra, A.; Boissière, A.; Bascunan, P.; Carrillo-Bustamante, P.; Camara, D.; Krüger, H.; Mariko, M.; Mariko, R.; et al. Mosquito Microevolution Drives Plasmodium Falciparum Dynamics. Nat. Microbiol. 2019, 4, 941-947. [CrossRef]

3. Hu, Y.-Q.; Gao, C.; Zhang, S.; Xu, L.; Xu, Z.; Feng, L.-S.; Wu, X.; Zhao, F. Quinoline Hybrids and Their Antiplasmodial and Antimalarial Activities. Eur. J. Med. Chem. 2017, 139, 22-47. [CrossRef]

4. Qin, H.-L.; Zhang, Z.-W.; Lekkala, R.; Alsulami, H.; Rakesh, K.P. Chalcone Hybrids as Privileged Scaffolds in Antimalarial Drug Discovery: A Key Review. Eur. J. Med. Chem. 2020, 193, 112215. [CrossRef] [PubMed]

5. Upadhyay, C.; Chaudhary, M.; De Oliveira, R.N.; Borbas, A.; Kempaiah, P.S.P.; Rathi, B. Fluorinated Scaffolds for Antimalarial Drug Discovery. Expert Opin. Drug Discov. 2020, 15, 705-718. [CrossRef] [PubMed]

6. Motika, S.E.; Hergenrother, P.J. Re-Engineering Natural Products to Engage New Biological Targets. Nat. Prod. Rep. 2020, 37, 1395-1403. [CrossRef] [PubMed]

7. Hong, B.; Luo, T.; Lei, X. Late-Stage Diversification of Natural Products. ACS Cent. Sci. 2020, 6, 622-635. [CrossRef] [PubMed]

8. Boratyński, P.J.; Zielińska-Błajet, M.; Skarżewski, J. Cinchona Alkaloids-Derivatives and Applications. In The Alkaloids: Chemistry and Biology; Knölker, H.-J., Ed.; Elsevier: Amsterdam, Netherlands, 2019; Volume 82, pp. 29-145. ISBN 978-0-12-817481-4.

9. Song, C.E. (Ed.) Cinchona Alkaloids in Synthesis and Catalysis: Ligands, Immobilization and Organocatalysis, 1st ed.; Wiley: Weinheim, Germany, 2009. ISBN 978-3-527-32416-3.

10. Wang, X.; Zeng, Y.; Sheng, L.; Larson, P.; Liu, X.; Zou, X.; Wang, S.; Guo, K.; Ma, C.; Zhang, G.; et al. A Cinchona Alkaloid Antibiotic That Appears To Target ATP Synthase in Streptococcus Pneumoniae. J. Med. Chem. 2019, 62, 2305-2332. [CrossRef]

11. Bawa, S.; Kumar, S.; Drabu, S.; Kumar, R. Structural Modifications of Quinoline-Based Antimalarial Agents: Recent Developments. J. Pharm. Bioallied Sci. 2010, 2, 64. [CrossRef]

12. Kaur, R.; Kumar, K. Synthetic and Medicinal Perspective of Quinolines as Antiviral Agents. Eur. J. Med. Chem. 2021, 215, 113220. [CrossRef]

13. Nqoro, X.; Tobeka, N.; Aderibigbe, B. Quinoline-Based Hybrid Compounds with Antimalarial Activity. Molecules 2017, $22,2268$. [CrossRef]

14. Njaria, P.M.; Okombo, J.; Njuguna, N.M.; Chibale, K. Chloroquine-Containing Compounds: A Patent Review (2010-2014). Expert Opin. Ther. Pat. 2015, 25, 1003-1024. [CrossRef]

15. Lutz, R.E.; Ohnmacht, C.J.; Patel, A.R. Antimalarials. 7. Bis(Trifluoromethyl)-Alpha-(2-Piperidyl)-4-Quinolinemethanols. J. Med. Chem. 1971, 14, 926-928. [CrossRef]

16. Adam, S. An Expedient and High Yielding Synthesis of Mefloquine. Via Fluoride Ion-Catalyzed Wittig Rearrangement, I. Tetrahedron 1989, 45, 1409-1414. [CrossRef]

17. Adam, S. A Straightforward Mid High Yielding Synthesis of Mefloquine-II. Tetrahedron 1991, 47, 7609-7614. [CrossRef]

18. Kumar, M.S.; Nageshwar, Y.V.D.; Meshram, H.M. A Facile and Alternative Method for the Synthesis of Mefloquine. Synth. Commun. 1996, 26, 1913-1919. [CrossRef]

19. Carroll, F.I.; Blackwell, J.T. Optical Isomers of Aryl-2-Piperidylmethanol Antimalarial Agents. Preparation, Optical Purity, and Absolute Stereochemistry. J. Med. Chem. 1974, 17, 210-219. (Note that absolute configuration of $(+)$ and (-) enantiomers is swapped in this paper). [CrossRef]

20. Baxter, A.; Harris, M.J.; Brown, S. Resolution of Mefloquine with O,O-Di-p-aroyltartaric Acid. Patent WO 2004050625 A1, 17 June 2004.

21. Kucharski, D.J.; Kowalczyk, R.; Boratyński, P.J. Chiral Vicinal Diamines Derived from Mefloquine. J. Org. Chem. 2021, 86, 10654-10664. [CrossRef]

22. Broger, E.A.; Hofheinz, W.; Meili, A. Asymmetrische Hydrierung. Patent EP 0553778 B1, 12 December 2001.

23. Schmid, R.; Broger, E.A.; Cereghetti, M.; Crameri, Y.; Foricher, J.; Lalonde, M.; Müller, R.K.; Scalone, M.; Schoettel, G.; Zutter, U. New Developments in Enantioselective Hydrogenation. Pure Appl. Chem. 1996, 68, 131-138. [CrossRef]

24. Xie, Z.-X.; Zhang, L.-Z.; Ren, X.-J.; Tang, S.-Y.; Li, Y. Asymmetric Synthesis of (+)-(11R,12S)-Mefloquine Hydrochloride. Chin. J. Chem. 2008, 26, 1272-1276. [CrossRef]

25. Knight, J.D.; Sauer, S.J.; Coltart, D.M. Asymmetric Total Synthesis of the Antimalarial Drug (+)-Mefloquine Hydrochloride via Chiral N-Amino Cyclic Carbamate Hydrazones. Org. Lett. 2011, 13, 3118-3121. [CrossRef] [PubMed]

26. Ding, J.; Hall, D.G. Concise Synthesis and Antimalarial Activity of All Four Mefloquine Stereoisomers Using a Highly Enantioselective Catalytic Borylative Alkene Isomerization. Angew. Chem. Int. Ed. 2013, 52, 8069-8073. [CrossRef] [PubMed]

27. Schützenmeister, N.; Müller, M.; Reinscheid, U.M.; Griesinger, C.; Leonov, A. Trapped in Misbelief for Almost 40 Years: Selective Synthesis of the Four Stereoisomers of Mefloquine. Chem. Eur. J. 2013, 19, 17584-17588. [CrossRef] [PubMed]

28. Zhou, G.; Liu, X.; Liu, X.; Nie, H.; Zhang, S.; Chen, W. A Stereospecific Synthesis and Unambiguous Assignment of the Absolute Configuration of (-)-Erythro-Mefloquine Hydrochloride. Adv. Synth. Catal. 2013, 355, 3575-3580. [CrossRef]

29. Hems, W.P.; Jackson, W.P.; Nightingale, P.; Bryant, R. Practical Asymmetric Synthesis of (+)-Erythro Mefloquine Hydrochloride. Org. Process Res. Dev. 2012, 16, 461-463. [CrossRef]

30. Rastelli, E.J.; Coltart, D.M. Asymmetric Synthesis of (+)-Anti-and (-)-Syn-Mefloquine Hydrochloride. J. Org. Chem. 2016, 81, 9567-9575. [CrossRef] 
31. Rastelli, E.J.; Coltart, D.M. A Concise and Highly Enantioselective Total Synthesis of (+)-Anti-and (-)-Syn-Mefloquine Hydrochloride: Definitive Absolute Stereochemical Assignment of the Mefloquines. Angew. Chem. Int.Ed. 2015, 54, 14070-14074. [CrossRef]

32. Wong, W.; Bai, X.-C.; Sleebs, B.E.; Triglia, T.; Brown, A.; Thompson, J.K.; Jackson, K.E.; Hanssen, E.; Marapana, D.S.; Fernandez, I.S.; et al. The Antimalarial Mefloquine Targets the Plasmodium Falciparum 80S Ribosome to Inhibit Protein Synthesis. Nat. Microbiol. 2017, 2, 17031. [CrossRef]

33. Piedade, R.; Traub, S.; Bitter, A.; Nüssler, A.K.; Gil, J.P.; Schwab, M.; Burk, O. Carboxymefloquine, the Major Metabolite of the Antimalarial Drug Mefloquine, Induces Drug-Metabolizing Enzyme and Transporter Expression by Activation of Pregnane $\mathrm{X}$ Receptor. Antimicrob. Agents Chemother. 2015, 59, 96-104. [CrossRef]

34. Grellepois, F.; Grellier, P.; Bonnet-Delpon, D.; Bégué, J.-P. Design, Synthesis and Antimalarial Activity of TrifluoromethylartemisininMefloquine Dual Molecules. ChemBioChem 2005, 6, 648-652. [CrossRef]

35. Müller, M.; Orben, C.M.; Schützenmeister, N.; Schmidt, M.; Leonov, A.; Reinscheid, U.M.; Dittrich, B.; Griesinger, C. The Absolute Configuration of (+)- and (-)-Erythro-Mefloquine. Angew. Chem. Int.Ed. 2013, 52, 6047-6049. [CrossRef]

36. Kreituss, I.; Chen, K.-Y.; Eitel, S.H.; Adam, J.-M.; Wuitschik, G.; Fettes, A.; Bode, J.W. A Robust, Recyclable Resin for Decagram Scale Resolution of $( \pm)$-Mefloquine and Other Chiral N-Heterocycles. Angew. Chem. Int. Ed. 2016, 55, 1553-1556. [CrossRef]

37. Kreituss, I.; Bode, J.W. Flow Chemistry and Polymer-Supported Pseudoenantiomeric Acylating Agents Enable Parallel Kinetic Resolution of Chiral Saturated N-Heterocycles. Nat. Chem. 2017, 9, 446-452. [CrossRef]

38. Lauterwasser, E.M.W.; Fontaine, S.D.; Li, H.; Gut, J.; Katneni, K.; Charman, S.A.; Rosenthal, P.J.; Bogyo, M.; Renslo, A.R. Trioxolane-Mediated Delivery of Mefloquine Limits Brain Exposure in a Mouse Model of Malaria. ACS Med. Chem. Lett. 2015, 6, 1145-1149. [CrossRef]

39. Chen, J.; Gonciarz, R.L.; Renslo, A.R. Expanded Scope of Griesbaum Co-Ozonolysis for the Preparation of Structurally Diverse Sensors of Ferrous Iron. RSC Adv. 2021, 11, 34338-34342. [CrossRef]

40. Jayaprakash, S.; Iso, Y.; Wan, B.; Franzblau, S.G.; Kozikowski, A.P. Design, Synthesis, and SAR Studies of Mefloquine-Based Ligands as Potential Antituberculosis Agents. ChemMedChem 2006, 1, 593-597. [CrossRef]

41. Kohout, M.; Vandenbussche, J.; Roller, A.; Tůma, J.; Bogaerts, J.; Bultinck, P.; Herrebout, W.; Lindner, W. Absolute Configuration of the Antimalarial Erythro-Mefloquine-Vibrational Circular Dichroism and X-Ray Diffraction Studies of Mefloquine and Its Thiourea Derivative. RSC Adv. 2016, 6, 81461-81465. [CrossRef]

42. Go, M.-L.; Lee, H.-S.; Ngiam, T.-L. Pharmacological Activity and Structure-Activity Relationship of ( \pm )-Erythro-Mefloquine and Related Compounds on the Isolated Mouse Phrenic Nerve Diaphragm Preparation. Biol. Pharm. Bull. 1993, 16, 668-674. [CrossRef]

43. Matoušek, V.; Pietrasiak, E.; Sigrist, L.; Czarniecki, B.; Togni, A. O-Trifluoromethylation of N,N-Disubstituted Hydroxylamines with Hypervalent Iodine Reagents. Eur. J. Org. Chem. 2014, 2014, 3087-3092. [CrossRef]

44. Lopchuk, J.M.; Fjelbye, K.; Kawamata, Y.; Malins, L.R.; Pan, C.-M.; Gianatassio, R.; Wang, J.; Prieto, L.; Bradow, J.; Brandt, T.A.; et al. Strain-Release Heteroatom Functionalization: Development, Scope, and Stereospecificity. J. Am. Chem. Soc. 2017, 139, 3209-3226. [CrossRef]

45. Engwerda, A.H.J.; Maassen, R.; Tinnemans, P.; Meekes, H.; Rutjes, F.P.J.T.; Vlieg, E. Attrition-Enhanced Deracemization of the Antimalaria Drug Mefloquine. Angew. Chem. Int. Ed. 2019, 58, 1670-1673. [CrossRef] [PubMed]

46. Tønnesen, H.H.; Grislingaas, A.-L. Photochemical Stability of Biologically Active Compounds. II. Photochemical Decomposition of Mefloquine in Water. Int. J. Pharm. 1990, 60, 157-162. [CrossRef]

47. Tønnesen, H.H. Photoreactivity of biologically active compounds. XV. Photochemical behaviour of mefloquine in aqueous solution. Pharmazie 1999, 54, 590-594.

48. Epling, G.A.; Yoon, U.C. Photochemical reactivity of mefloquine, a new synthetic antimalarial. Chem. Lett. 1982, 11, 211-214. [CrossRef]

49. Ouji, M.; Nguyen, M.; Mustière, R.; Jimenez, T.; Augereau, J.-M.; Benoit-Vical, F.; Deraeve, C. Novel Molecule Combinations and Corresponding Hybrids Targeting Artemisinin-Resistant Plasmodium Falciparum Parasites. Bioorg. Med. Chem. Lett. 2021, 39, 127884. [CrossRef] [PubMed]

50. Maier, N.M.; Nicoletti, L.; Lämmerhofer, M.; Lindner, W. Enantioselective Anion Exchangers Based on Cinchona Alkaloid-Derived Carbamates: Influence of C8/C9 Stereochemistry on Chiral Recognition. Chirality 1999, 11, 522-528. [CrossRef]

51. Zarbl, E.; Lämmerhofer, M.; Franco, P.; Petracs, M.; Lindner, W. Development of Stereoselective Nonaqueous Capillary Electrophoresis System for the Resolution of Cationic and Amphoteric Analytes. Electrophoresis 2001, 22, 3297-3307. [CrossRef]

52. Zarbl, E.; Lammerhofer, M.; Woschek, A.; Hammerschmidt, F.; Parenti, C.; Cannazza, G.; Lindner, W. Strong versus Weak Chiral Cation Exchangers: Comparative Evaluation for Enantiomer Separation of Chiral Bases by Non-Aqueous CEC. J. Sep. Sci. 2002, 25, 1269-1283. [CrossRef]

53. Hebenstreit, D.; Bicker, W.; Lämmerhofer, M.; Lindner, W. Novel Enantioselective Strong Cation Exchangers Based on Sulfodipeptide Selectors: Evaluation for Enantiomer Separation of Chiral Bases by Nonaqueous Capillary Electrochromatography. Electrophoresis 2004, 25, 277-289. [CrossRef]

54. Preinerstorfer, B.; Lindner, W.; Lämmerhofer, M. Polymethacrylate-Type Monoliths Functionalized with Chiral Amino Phosphonic Acid-Derived Strong Cation Exchange Moieties for Enantioselective Nonaqueous Capillary Electrochromatography and Investigation of the Chemical Composition of the Monolithic Polymer. Electrophoresis 2005, 26, 2005-2018. [CrossRef] 
55. Preinerstorfer, B.; Lämmerhofer, M.; Hoffmann, C.V.; Lubda, D.; Lindner, W. Deconvolution of Electrokinetic and Chromatographic Contributions to Solute Migration in Stereoselective Ion-Exchange Capillary Electrochromatography on Monolithic Silica Capillary Columns. J. Sep. Sci. 2008, 31, 3065-3078. [CrossRef]

56. Preinerstorfer, B.; Hoffmann, C.; Lubda, D.; Lämmerhofer, M.; Lindner, W. Enantioselective Silica-Based Monoliths Modified with a Novel Aminosulfonic Acid-Derived Strong Cation Exchanger for Electrically Driven and Pressure-Driven Capillary Chromatography. Electrophoresis 2008, 29, 1626-1637. [CrossRef]

57. Preinerstorfer, B.; Lubda, D.; Lindner, W.; Lämmerhofer, M. Monolithic Silica-Based Capillary Column with Strong Chiral Cation-Exchange Type Surface Modification for Enantioselective Non-Aqueous Capillary Electrochromatography. J. Chromatogr. A 2006, 1106, 94-105. [CrossRef]

58. Hoffmann, C.V.; Laemmerhofer, M.; Lindner, W. Novel Strong Cation-Exchange Type Chiral Stationary Phase for the Enantiomer Separation of Chiral Amines by High-Performance Liquid Chromatography. J. Chromatogr. A 2007, 1161, 242-251. [CrossRef]

59. Hoffmann, C.V.; Pell, R.; Lämmerhofer, M.; Lindner, W. Synergistic Effects on Enantioselectivity of Zwitterionic Chiral Stationary Phases for Separations of Chiral Acids, Bases, and Amino Acids by HPLC. Anal. Chem. 2008, 80, 8780-8789. [CrossRef]

60. Wernisch, S.; Pell, R.; Lindner, W. Increments to Chiral Recognition Facilitating Enantiomer Separations of Chiral Acids, Bases, and Ampholytes Using Cinchona-Based Zwitterion Exchanger Chiral Stationary Phases. J. Sep. Sci. 2012, 35, 1560-1572. [CrossRef]

61. Wolrab, D.; Fruehauf, P.; Kohout, M.; Lindner, W. Click Chemistry Immobilization Strategies in the Development of Strong Cation Exchanger Chiral Stationary Phases for HPLC. J. Sep. Sci. 2013, 36, 2826-2837. [CrossRef]

62. Wolrab, D.; Kohout, M.; Boras, M.; Lindner, W. Strong Cation Exchange-Type Chiral Stationary Phase for Enantioseparation of Chiral Amines in Subcritical Fluid Chromatography. J. Chromatogr. A 2013, 1289, 94-104. [CrossRef]

63. Wolrab, D.; Macikova, P.; Boras, M.; Kohout, M.; Lindner, W. Strong Cation Exchange Chiral Stationary Phase-A Comparative Study in High-Performance Liquid Chromatography and Subcritical Fluid Chromatography. J. Chromatogr. A 2013, 1317, 59-66. [CrossRef]

64. Kohout, M.; Kählig, H.; Wolrab, D.; Roller, A.; Lindner, W. Novel Chiral Selector Based on Mefloquine-A Comparative NMR Study to Elucidate Intermolecular Interactions with Acidic Chiral Selectands. Chirality 2012, 24, 936-943. [CrossRef]

65. Gillespie, R.J.; Lerpiniere, J.; Giles, P.R.; Adams, D.R.; Knutsen, L.J.S.; Cliffe, I.A. 4-Quinolinemethanol Derivatives as Purine Receptor Antagonists (II). Patent US 6608085 B1, 19 August 2003.

66. Brossi, A.; Silverton, J.V.; Rösner, M. Structure, Chemistry, and Antimalarial Properties of Mefloquine-aziridine. Heterocycles 1981, 15, 925-933. [CrossRef]

67. Mbela, T.K.M.N.; Ludwig, A.; Landau, I.; Deharo, E.; Haemers, A. Preparation, Characterization and in Vivo Activity of Mefloquine Submicron Emulsions. Int. J. Pharm. 1994, 110, 189-196. [CrossRef]

68. Gonçalves, R.S.B.; Kaiser, C.R.; Lourenço, M.C.S.; de Souza, M.V.N.; Wardell, J.L.; Wardell, S.M.S.V.; da Silva, A.D. Synthesis and Antitubercular Activity of New Mefloquine-Oxazolidine Derivatives. Eur. J. Med. Chem. 2010, 45, 6095-6100. [CrossRef] [PubMed]

69. Wardell, J.L.; Wardell, S.M.S.V.; Tiekink, E.R.T. 4-(3,3-Dimethylperhydro-1,3-Oxazolo[3,4-a]Pyridin-1-Y1)-2,8-Bis(Trifluoromethyl)Q uinoline. Acta Crystallogr. E 2010, 66, o700-o701. [CrossRef]

70. Gonçalves, R.S.B.; Kaiser, C.R.; Lourenço, M.C.S.; Bezerra, F.A.F.M.; de Souza, M.V.N.; Wardell, J.L.; Wardell, S.M.S.V.; das Henriques, M.G.M.; de Costa, T.O. Mefloquine-Oxazolidine Derivatives, Derived from Mefloquine and Arenecarbaldehydes: In Vitro Activity Including against the Multidrug-Resistant Tuberculosis Strain T113. Bioorg. Med. Chem. 2012, 20, 243-248. [CrossRef]

71. Rodrigues, F.A.R.; da Bomfim, I.S.; Cavalcanti, B.C.; Pessoa, C.; Goncalves, R.S.B.; Wardell, J.L.; Wardell, S.M.S.V.; de Souza, M.V.N. Mefloquine-Oxazolidine Derivatives: A New Class of Anticancer Agents. Chem. Biol. Drug Des. 2014, 83, 126-131. [CrossRef]

72. Wardell, J.L.; de Souza, M.V.N.; Wardell, S.M.S.V.; Lourenço, M.C.S. Mefloquine Derivatives: Crystal Structures and AntiTubercular Activities of Diphenyl[(( $\left.\mathrm{R}^{*}, \mathrm{~S}^{*}\right)$-2,8-Bis(Trifluoromethyl)Quinolin-4-yl)-Piperidin-2-yl-Methanolato-O,N]Boron and ( \pm )-Erythro-Mefloquinium Tetraphenylborate Solvates. J. Mol. Struct. 2011, 990, 67-74. [CrossRef]

73. Hubel, R.; Polborn, K.; Knizek, J.; Nöth, H.; Beck, W. Palladium(II)- und Platin(II)-Komplexe mit dem Antimalariamittel Mefloquin als Liganden. Z. Anorg. Allg. Chem. 2000, 626, 1701-1708. [CrossRef]

74. Coronado, L.M.; Nadovich, C.T.; Spadafora, C. Malarial Hemozoin: From Target to Tool. Biochim. Biophys. Acta 2014, 1840, 2032-2041. [CrossRef]

75. De Villiers, K.A.; Gildenhuys, J.; le Roex, T. Iron(III) Protoporphyrin IX Complexes of the Antimalarial Cinchona Alkaloids Quinine and Quinidine. ACS Chem. Biol. 2012, 7, 666-671. [CrossRef]

76. Gildenhuys, J.; Sammy, C.J.; Müller, R.; Streltsov, V.A.; le Roex, T.; Kuter, D.; de Villiers, K.A. Alkoxide Coordination of Iron(III) Protoporphyrin IX by Antimalarial Quinoline Methanols: A Key Interaction Observed in the Solid-State and Solution. Dalton Trans. 2015, 44, 16767-16777. [CrossRef]

77. Andersag, H.; Breitner, S.; Jung, H. Process for the preparation of quinoline compounds containing amino groups with basic substituents in the 4-position. Patent DE 683692, 13 November 1939.

78. Kenyon, R.L.; Wiesner, J.A.; Kwartler, C.E. Chloroquine Manufacture. Ind. Eng. Chem. 1949, 41, 654-662. [CrossRef]

79. Surrey, A.R. 7-Chloro-4-[5-(n-Ethyl-n-2-Hydroxyethylamino)-2-Pentyl] Aminoquinoline, Its Acid Addition Salts, and Method of Preparation. Patent US 2546658, 27 March 1951. 
80. Finbloom, D.S.; Silver, K.; Newsome, D.A.; Gunkel, R. Comparison of Hydroxychloroquine and Chloroquine Use and the Development of Retinal Toxicity. J. Rheumatol. 1985, 12, 692-694.

81. Van Schalkwyk, D.A.; Burrow, R.; Henriques, G.; Gadalla, N.B.; Beshir, K.B.; Hasford, C.; Wright, S.G.; Ding, X.C.; Chiodini, P.L.; Sutherland, C.J. Culture-Adapted Plasmodium Falciparum Isolates from UK Travellers: In Vitro Drug Sensitivity, Clonality and Drug Resistance Markers. Malar. J. 2013, 12, 320. [CrossRef]

82. Schrezenmeier, E.; Dörner, T. Mechanisms of Action of Hydroxychloroquine and Chloroquine: Implications for Rheumatology. Nat. Rev. Rheumatol. 2020, 16, 155-166. [CrossRef]

83. Savarino, A.; Boelaert, J.R.; Cassone, A.; Majori, G.; Cauda, R. Effects of Chloroquine on Viral Infections: An Old Drug against Today's Diseases. Lancet Infect. Dis. 2003, 3, 722-727. [CrossRef]

84. Lamontagne, F.; Agoritsas, T.; Siemieniuk, R.; Rochwerg, B.; Bartoszko, J.; Askie, L.; Macdonald, H.; Amin, W.; Bausch, F.J.; Burhan, E.; et al. A Living WHO Guideline on Drugs to Prevent Covid-19. BMJ 2021, n526. [CrossRef]

85. Browning, D.J. Pharmacology of Chloroquine and Hydroxychloroquine. In Hydroxychloroquine and Chloroquine Retinopathy; Browning, D.J., Ed.; Springer: New York, NY, USA, 2014; pp. 35-63. ISBN 978-1-4939-0597-3. [CrossRef]

86. Li, X.-Q.; Björkman, A.; Andersson, T.B.; Gustafsson, L.L.; Masimirembwa, C.M. Identification of Human Cytochrome P450s That Metabolise Anti-Parasitic Drugs and Predictions of in Vivo Drug Hepatic Clearance from in Vitro Data. Eur. J. Clin. Pharmacol. 2003, 59, 429-442. [CrossRef]

87. Ducharme, J.; Farinotti, R. Clinical Pharmacokinetics and Metabolism of Chloroquine. Clin. Pharmacokinet. 1996, 31, $257-274$. [CrossRef]

88. Biot, C.; Delhaes, L.; Abessolo, H.; Domarle, O.; Maciejewski, L.A.; Mortuaire, M.; Delcourt, P.; Deloron, P.; Camus, D.; Dive, D.; et al. Novel Metallocenic Compounds as Antimalarial Agents. Study of the Position of Ferrocene in Chloroquine. J. Organomet. Chem 1999, 589, 59-65. [CrossRef]

89. Edaye, S.; Tazoo, D.; Bohle, D.S.; Georges, E. 3-Iodo-4-Aminoquinoline Derivative Sensitises Resistant Strains of Plasmodium Falciparum to Chloroquine. Int. J. Antimicrob. Agents 2016, 47, 482-485. [CrossRef]

90. Brewer, J.R.; Jones, J.R.; Lawrie, K.W.M.; Saunders, D.; Simmonds, A. Tritiation of Organic Compounds by Polymer-Supported Acid Catalysts. J. Label. Compd. Radiopharm. 1994, 34, 391-400. [CrossRef]

91. Wanjari, A.K. Synthesis of N-[7-(1-Substituted) -2,4-Dithiobiureto)-4-YL]-N,N-Diethyl-Pentane-1,4-Diamine. Orient. J. Chem. 2011, $27,1787-1790$.

92. Lipshutz, B.H.; Tomioka, T.; Pfeiffer, S.S. Mild and Selective Reductions of Aryl Halides Catalyzed by Low-Valent Nickel Complexes. Tetrahedron Lett. 2001, 42, 7737-7740. [CrossRef]

93. Kuriyama, M.; Hamaguchi, N.; Yano, G.; Tsukuda, K.; Sato, K.; Onomura, O. Deuterodechlorination of Aryl/Heteroaryl Chlorides Catalyzed by a Palladium/Unsymmetrical NHC System. J. Org. Chem. 2016, 81. [CrossRef] [PubMed]

94. Boeckman, R.; Boyce, B.; Xiao, L.; Yao, Z.; Ebetino, F.H. Phosphonate-Chloroquine Conjugates and Methods Using Same. Patent WO 2017079260 A1, 11 May 2017.

95. Sun, S.; Tao, J.; Sedghizadeh, P.P.; Cherian, P.; Junka, A.F.; Sodagar, E.; Xing, L.; Boeckman Jr, R.K.; Srinivasan, V.; Yao, Z.; et al. Bisphosphonates for Delivering Drugs to Bone. Br. J. Pharmacol. 2021, 178, 2008-2025. [CrossRef] [PubMed]

96. Joshi, P.; Chakraborty, S.; Dey, S.; Shanker, V.; Ansari, Z.A.; Singh, S.P.; Chakrabarti, P. Binding of Chloroquine-Conjugated Gold Nanoparticles with Bovine Serum Albumin. J. Colloid Interface Sci. 2011, 355, 402-409. [CrossRef] [PubMed]

97. Joshi, P.; Chakraborti, S.; Ramirez-Vick, J.E.; Ansari, Z.A.; Shanker, V.; Chakrabarti, P.; Singh, S.P. The Anticancer Activity of Chloroquine-Gold Nanoparticles against MCF-7 Breast Cancer Cells. Colloids Surf. B 2012, 95, 195-200. [CrossRef]

98. Tota, A.; Colella, M.; Carlucci, C.; Aramini, A.; Clarkson, G.; Degennaro, L.; Bull, J.A.; Luisi, R. N-N Bond Formation Using an Iodonitrene as an Umpolung of Ammonia: Straightforward and Chemoselective Synthesis of Hydrazinium Salts. Adv. Synth. Catal. 2021, 363, 194-199. [CrossRef]

99. Montzka, T.A.; Matiskella, J.D.; Partyka, R.A. 2,2,2-Trichloroethyl Chloroformate: A General Reagent for Demethylation of Tertiary Methylamines. Tetrahedron Lett. 1974, 15, 1325-1327. [CrossRef]

100. Ansari, A.M.; Craig, J.C. A Convenient, Short Synthesis of Desethylchloroquine [7-Chloro-4-(4'-Ethylamino-1'-MethylButylamino)Quinoline]. Synthesis 1995, 1995, 147-149. [CrossRef]

101. Carmack, M.; Bullitt, O.H.; Handrick, G.R.; Kissinger, L.W.; Von, I. The Synthesis of 4-(4'-Amino-1'-Methylbutylamino)-7Chloroquinoline and Some 4-(4'-Monoalkylamino-1'-Methylbutylamino) -7-Chloroquinolines1. J. Am. Chem. Soc. 1946, 68, 1220-1225. [CrossRef]

102. Nord, K.; Karlsen, J.; Tønnesen, H.H. Photochemical Stability of Biologically Active Compounds. IV. Photochemical Degradation of Chloroquine. Int. J. Pharm. 1991, 72, 11-18. [CrossRef]

103. Moore, D.E.; Hemmens, V.J. Photosensitization by Antimalarial Drugs. Photochem. Photobiol. 1982, 36, 71-77. [CrossRef]

104. Nord, K.; Orsteen, A.L.; Karlsen, J.; Tønnesen, H.H. Photoreactivity of Biological Active Compounds, X: Photoreactivity of Chloroquine in Aqueous Solution. Pharmazie 1997, 52, 598-603.

105. Li, Z.; Yazaki, R.; Ohshima, T. Chemo- and Regioselective Direct Functional Group Installation through Catalytic Hydroxy Group Selective Conjugate Addition of Amino Alcohols to $\alpha, \beta$-Unsaturated Sulfonyl Compounds. Org. Lett. 2016, 18, $3350-3353$. [CrossRef] 
106. Li, Z.; Tamura, M.; Yazaki, R.; Ohshima, T. Catalytic Chemoselective Conjugate Addition of Amino Alcohols to $\alpha, \beta$-Unsaturated Ester: Hydroxy Group over Amino Group and Conjugate Addition over Transesterification. Chem. Pharm. Bull. 2017, 65, 19-21. [CrossRef]

107. Poorvashree, J.; Suneela, D. Novel Drug Delivery of Dual Acting Prodrugs of Hydroxychloroquine with Aryl Acetic Acid NSAIDs: Design, Kinetics and Pharmacological Study. Drug Deliv. Transl. Res. 2017, 7, 709-730. [CrossRef]

108. Davioud-Charvet, E.; Delarue, S.; Biot, C.; Schwöbel, B.; Boehme, C.C.; Müssigbrodt, A.; Maes, L.; Sergheraert, C.; Grellier, P.; Schirmer, R.H.; et al. A Prodrug Form of a Plasmodium Falciparum Glutathione Reductase Inhibitor Conjugated with a 4-Anilinoquinoline. J. Med. Chem. 2001, 44, 4268-4276. [CrossRef]

109. Horikawa, R.; Fujimoto, C.; Yazaki, R.; Ohshima, T. M-Oxo-Dinuclear-Iron(III)-Catalyzed O-Selective Acylation of Aliphatic and Aromatic Amino Alcohols and Transesterification of Tertiary Alcohols. Chem. Eur. J. 2016, 22, 12278-12281. [CrossRef]

110. Song, Z.; Liu, Y.; Xie, C.; Tong, X.; Wang, X.; Zhou, Y.; Gu, W.; Zuo, J.; He, S.; Zhang, A. Synthesis and Pharmacological Evaluation of Choroquine Derivatives Bearing Long Aminated Side Chains as Antivirus and Anti-Inflammatory Agents. Bioorg. Chem. 2021, 116, 105346. [CrossRef] [PubMed]

111. Sleightholm, R.; Yang, B.; Yu, F.; Xie, Y.; Oupický, D. Chloroquine-Modified Hydroxyethyl Starch as a Polymeric Drug for Cancer Therapy. Biomacromolecules 2017, 18, 2247-2257. [CrossRef] [PubMed]

112. Yu, F.; Xie, Y.; Wang, Y.; Peng, Z.-H.; Li, J.; Oupický, D. Chloroquine-Containing HPMA Copolymers as Polymeric Inhibitors of Cancer Cell Migration Mediated by the CXCR4/SDF-1 Chemokine Axis. ACS Macro Lett. 2016, 5, 342-345. [CrossRef] [PubMed]

113. Yu, F.; Li, J.; Xie, Y.; Sleightholm, R.L.; Oupický, D. Polymeric Chloroquine as an Inhibitor of Cancer Cell Migration and Experimental Lung Metastasis. J. Control. Release 2016, 244, 347-356. [CrossRef]

114. Yu, F.; Wang, Y.; Hang, Y.; Tang, W.; Zhao, Z.; Oupický, D. Synthesis and Biological Characterization of Clicked Chloroquine Copolymers as Macromolecular Inhibitors of Cancer Cell Migration. J. Polym. Sci. Polym. Chem. 2019, 57, 2235-2242. [CrossRef]

115. Perche, F.; Yi, Y.; Hespel, L.; Mi, P.; Dirisala, A.; Cabral, H.; Miyata, K.; Kataoka, K. Hydroxychloroquine-Conjugated Gold Nanoparticles for Improved SiRNA Activity. Biomaterials 2016, 90, 62-71. [CrossRef]

116. Ghoreishi, S.M.; Attaran, A.M.; Amin, A.M.; Khoobi, A. Multiwall Carbon Nanotube-Modified Electrode as a Nanosensor for Electrochemical Studies and Stripping Voltammetric Determination of an Antimalarial Drug. RSC Adv. 2015, 5, 14407-14415. [CrossRef]

117. Navarro, M.; Pérez, H.; Sánchez-Delgado, R.A. Toward a Novel Metal-Based Chemotherapy against Tropical Diseases. 3. Synthesis and Antimalarial Activity in Vitro and in Vivo of the New Gold-Chloroquine Complex [Au(PPh3)(CQ)]PF6. J. Med. Chem. 1997, 40, 1937-1939. [CrossRef]

118. Navarro, M.; Vásquez, F.; Sánchez-Delgado, R.A.; Pérez, H.; Sinou, V.; Schrével, J. Toward a Novel Metal-Based Chemotherapy against Tropical Diseases. 7. Synthesis and in Vitro Antimalarial Activity of New Gold-Chloroquine Complexes. J. Med. Chem. 2004, 47, 5204-5209. [CrossRef]

119. Blackie, M.A.L.; Beagley, P.; Chibale, K.; Clarkson, C.; Moss, J.R.; Smith, P.J. Synthesis and Antimalarial Activity in Vitro of New Heterobimetallic Complexes: Rh and Au Derivatives of Chloroquine and a Series of Ferrocenyl-4-Amino-7-Chloroquinolines. J. Organomet. Chem. 2003, 688, 144-152. [CrossRef]

120. Hitosugi-Levesque, M.; Tanski, J.M. \{4-[(7-Chloro-4-Quinolyl)Amino]-N,N-Diethylpentanaminium\}(Triphenylphosphine) Gold(I) Dinitrate. Acta Crystallogr. E 2010, 66, m1098-m1099. [CrossRef]

121. De Souza Pereira, C.; Costa Quadros, H.; Magalhaes Moreira, D.R.; Castro, W.; Santos De Deus Da Silva, R.I.; Botelho Pereira Soares, M.; Fontinha, D.; Prudêncio, M.; Schmitz, V.; Dos Santos, H.F.; et al. Novel Hybrid of Chloroquine and Primaquine Linked by Gold(I): Multitarget and Multiphase Antiplasmodial Agent. ChemMedChem 2021, 16, 662-678. [CrossRef]

122. Rajapakse, C.S.K.; Martínez, A.; Naoulou, B.; Jarzecki, A.A.; Suárez, L.; Deregnaucourt, C.; Sinou, V.; Schrével, J.; Musi, E.; Ambrosini, G.; et al. Synthesis, Characterization, and in Vitro Antimalarial and Antitumor Activity of New Ruthenium(II) Complexes of Chloroquine. Inorg. Chem. 2009, 48, 1122-1131. [CrossRef]

123. Patra, M.; Joshi, T.; Pierroz, V.; Ingram, K.; Kaiser, M.; Ferrari, S.; Spingler, B.; Keiser, J.; Gasser, G. DMSO-Mediated Ligand Dissociation: Renaissance for Biological Activity of N-Heterocyclic-[Ru(H6-Arene)Cl2] Drug Candidates. Chem. Eur. J. 2013, 19, 14768-14772. [CrossRef]

124. Colina-Vegas, L.; Villarreal, W.; Navarro, M.; de Oliveira, C.R.; Graminha, A.E.; da Maia, P.I.S.; Deflon, V.M.; Ferreira, A.G.; Cominetti, M.R.; Batista, A.A. Cytotoxicity of Ru(II) Piano-Stool Complexes with Chloroquine and Chelating Ligands against Breast and Lung Tumor Cells: Interactions with DNA and BSA. J. Inorg. Biochem. 2015, 153, 150-161. [CrossRef]

125. Sánchez-Delgado, R.A.; Navarro, M.; Pérez, H.; Urbina, J.A. Toward a Novel Metal-Based Chemotherapy against Tropical Diseases. 2. Synthesis and Antimalarial Activity in Vitro and in Vivo of New Ruthenium - and Rhodium-Chloroquine Complexes. J. Med. Chem. 1996, 39, 1095-1099. [CrossRef]

126. Villarreal, W.; Colina-Vegas, L.; Rodrigues de Oliveira, C.; Tenorio, J.C.; Ellena, J.; Gozzo, F.C.; Cominetti, M.R.; Ferreira, A.G.; Ferreira, M.A.B.; Navarro, M.; et al. Chiral Platinum(II) Complexes Featuring Phosphine and Chloroquine Ligands as Cytotoxic and Monofunctional DNA-Binding Agents. Inorg. Chem. 2015, 54, 11709-11720. [CrossRef]

127. Navarro, M.; Castro, W.; Higuera-Padilla, A.R.; Sierraalta, A.; Abad, M.J.; Taylor, P.; Sánchez-Delgado, R.A. Synthesis, Characterization and Biological Activity of Trans-Platinum(II) Complexes with Chloroquine. J. Inorg. Biochem. 2011, 105, 1684-1691. [CrossRef] 
128. Ibrahim, S.; Tagami, T.; Ozeki, T. Effective-Loading of Platinum-Chloroquine into PEGylated Neutral and Cationic Liposomes as a Drug Delivery System for Resistant Malaria Parasites. Biol. Pharm. Bull. 2017, 40, 815-823. [CrossRef]

129. Ajibade, P.A.; Kolawole, G.A. Synthesis, Characterization and Antiprotozoal Studies of Some Metal Complexes of Antimalarial Drugs. Transition Met. Chem. 2008, 33, 493-497. [CrossRef]

130. Navarro, M.; Peña, N.P.; Colmenares, I.; González, T.; Arsenak, M.; Taylor, P. Synthesis and Characterization of New PalladiumClotrimazole and Palladium-Chloroquine Complexes Showing Cytotoxicity for Tumor Cell Lines in Vitro. J. Inorg. Biochem. 2006, 100, 152-157. [CrossRef] [PubMed]

131. Navarro, M.; Pekerar, S.; Pérez, H.A. Synthesis, Characterization and Antimalarial Activity of New Iridium-Chloroquine Complexes. Polyhedron 2007, 26, 2420-2424. [CrossRef]

132. Ajibade, P.A.; Kolawole, G.A. Cobalt(III) Complexes of Some Antimalarial Drugs: Synthesis, Characterization, and in Vitro Antiprotozoal Studies. Synth. React. Met.-Org. Inorg. Nano-Met. Chem. 2010, 40, 273-278. [CrossRef]

133. Maurya, R.C.; Mishra, D.D.; Pillai, V. Studies on Some Novel Mixed-Ligand Oxovanadium(IV) Complexes Involving Acetylacetone and Nitrogen or Oxygen Donor Organic Compounds. Synth. React. Inorg. Met.-Org. Chem. 1995, 25, 1127-1141. [CrossRef]

134. Maurya, R.C.; Mishra, D.D. Preparation and Physico-Chemical Studies of Some Novel Mixed-Ligand Cyanonitrosyl CrNO5 Complexes of Chromium(I) with Some Antimalarial, Antibacterial and Antidyspeptic Drugs. Synth. React. Inorg. Met.-Org. Chem. 1991, 21, 1627-1639. [CrossRef]

135. Navarro, M.; Goitia, H.; Silva, P.; Velásquez, M.; Ojeda, L.E.; Fraile, G. Synthesis and Characterization of New Copper- and Zinc-Chloroquine Complexes and Their Activities on Respiratory Burst of Polymorphonuclear Leukocytes. J. Inorg. Biochem. 2005, 99, 1630-1636. [CrossRef]

136. Kadam, M.S.; Khiste, S.A.; Dake, S.A.; Khade, B.C. Studies on X-Ray Diffraction, Thermogravimetric Stability, AntibacterialAntifungal Activity of $\mathrm{Fe}(\mathrm{II}), \mathrm{Ni}(\mathrm{II}), \mathrm{Cu}(\mathrm{II})$ Metal Chloroquine Complexes Against Bacterial Strains and Fungal Spore. Antiinfect. Agents 2020, 18, 339-351. [CrossRef]

137. Shi, Z.; Chen, X.; Zhang, L.; Ding, S.; Wang, X.; Lei, Q.; Fang, W. FA-PEG Decorated MOF Nanoparticles as a Targeted Drug Delivery System for Controlled Release of an Autophagy Inhibitor. Biomater. Sci. 2018, 6, 2582-2590. [CrossRef]

138. Jodłowski, P.J.; Kurowski, G.; Kuterasiński, Ł.; Sitarz, M.; Jeleń, P.; Jaśkowska, J.; Kołodziej, A.; Pajdak, A.; Majka, Z.; BoguszewskaCzubara, A. Cracking the Chloroquine Conundrum: The Application of Defective UiO-66 Metal-Organic Framework Materials to Prevent the Onset of Heart Defects-In Vivo and In Vitro. ACS Appl. Mater. Interfaces 2021, 13, 312-323. [CrossRef]

139. Zhang, L.; Tian, J.; Cao, F.; Zhu, Z.-Y.; Hong, F.; Wu, J.; Wang, F. Titanium-Based Metal-Organic Frameworks as Potential Chloroquine Drug Carriers. Inorg. Chem. Commun. 2021, 133, 108870. [CrossRef]

140. Roy, A.; Saha, S.; Roy, D.; Bhattacharyya, S.; Roy, M.N. Formation \& Specification of Host-Guest Inclusion Complexes of an Anti-Malarial Drug inside into Cyclic Oligosaccharides for Enhancing Bioavailability. J. Incl. Phenom. Macrocycl. Chem. 2020, 97, 65-76. [CrossRef]

141. Kwong, C.H.T.; Mu, J.; Li, S.; Fang, Y.; Liu, Q.; Zhang, X.; Kam, H.; Lee, S.M.Y.; Chen, Y.; Deng, F.; et al. Reviving Chloroquine for Anti-SARS-CoV-2 Treatment with Cucurbit[7]Uril-Based Supramolecular Formulation. Chin. Chem. Lett. 2021, 32, $3019-3022$. [CrossRef]

142. Kuter, D.; Benjamin, S.J.; Egan, T.J. Multiple Spectroscopic and Magnetic Techniques Show That Chloroquine Induces Formation of the $\mu$-Oxo Dimer of Ferriprotoporphyrin IX. J. Inorg. Biochem. 2014, 133, 40-49. [CrossRef]

143. Walczak, M.S.; Lawniczak-Jablonska, K.; Wolska, A.; Sienkiewicz, A.; Suárez, L.; Kosar, A.J.; Bohle, D.S. Understanding Chloroquine Action at the Molecular Level in Antimalarial Therapy: X-Ray Absorption Studies in Dimethyl Sulfoxide Solution. J. Phys. Chem. B 2011, 115, 1145-1150. [CrossRef]

144. Constantinidis, I.; Satterlee, J. UVVisible and Carbon NMR Studies of Chloroquine Binding to Urohemin I Chloride and Uroporphyrin I in Aqueous Solutions. J. Am. Chem. Soc. 1988, 110, 4391-4395. [CrossRef]

145. Dodd, E.L.; Bohle, D.S. Orienting the Heterocyclic Periphery: A Structural Model for Chloroquine's Antimalarial Activity. Chem. Commun. 2014, 50, 13765-13768. [CrossRef]

146. Arya, B.D.; Mittal, S.; Joshi, P.; Pandey, A.K.; Ramirez-Vick, J.E.; Singh, S.P. Graphene Oxide-Chloroquine Nanoconjugate Induce Necroptotic Death in A549 Cancer Cells through Autophagy Modulation. Nanomedicine 2018, 13, 2261-2282. [CrossRef]

147. Tripathy, S.; Chattopadhyay, S.; Dash, S.K.; Ray Chowdhuri, A.; Das, S.; Sahu, S.K.; Majumdar, S.; Roy, S. Chitosan Conjugated Chloroquine: Proficient to Protect the Induction of Liver Apoptosis during Malaria. Int. J. Biol. Macromol. 2015, 74, 585-600. [CrossRef] 